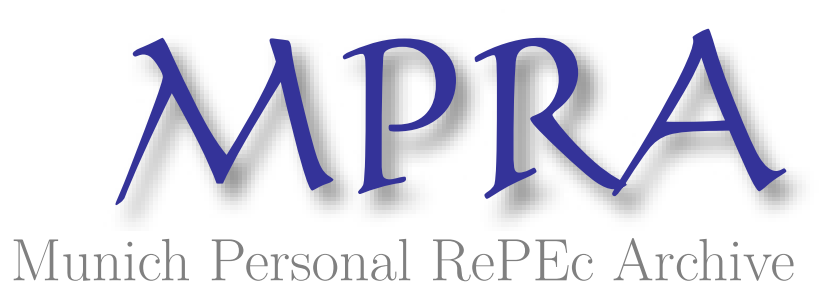

\title{
Instruments of Trade Policy
}

Jehle, Geoffrey

Vassar College

2013

Online at https://mpra.ub.uni-muenchen.de/73428/

MPRA Paper No. 73428, posted 03 Sep 2016 14:54 UTC 


\section{P A R T I I I}

\section{TRADE POLICY}

AND TRADE

LIBERALIZATION

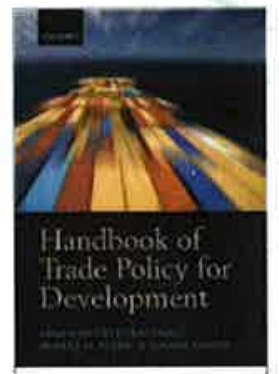

Handbook of Trade Policy for Development

Arvid Lukauskas, Robert M. Stern, and Gianni Zanini

Print publication date: 2013

Print ISBN-13: 9780199680405

Published to Oxford Scholarship Online: January 2014

DOI: $10.1093 /$ acprof:oso/9780199680405.001.0001 



\title{
CHAPTER 6
}

\section{NSTRUMENTS OF TRADE POLICY}

\author{
GEOFFREY A. JEHLE
}

\section{INTRODUCTION}

Governments implement a variety of policies targeting international trade-both imports and exports - and they do so for a variety of reasons. In this chapter, we examine the principal instruments of trade policy used by modern governments. Our goal will be to understand the impact each one has on the allocation of resources and on the distribution of welfare to consumers, producers, and government in the country that employs it.

\section{IMPORT TARIFFS}

\section{The Many Types of Tariffs}

\section{Ad valorem and specific tariffs}

A tariff is a tax on imports. An ad valorem tariff is expressed as a per cent of the imported good's value or price: a 10 per cent tax on the price of imported tomatoes is an example of an ad valorem tariff. A specific tariff is expressed as a fixed amount of money per unit of the good: a charge of $\$ 20$ per 100 pounds of imported tomatoes is an example of a specific tariff. Of course, each type of tariff can be directly converted into an equivalent tariff of the other type. For example, if the price of imported tomatoes is $\$ 200$ per 100 pounds, the 10 per cent ad valorem tariff is equivalent to the $\$ 20$ specific tariff-each requires the importer to pay a customs duty of $\$ 20$ on one 100 pounds of tomatoes. As part of the "July 2004 Package" of the Doha Development Agenda, member countries of the WTO have now agreed to work toward converting all non-ad valorem tariffs to their ad valorem equivalents and to henceforth base negotiations on those. In this chapter, we 
will always speak in terms of ad valorem tariffs. Of course, because of their ready convertibility, conclusions regarding ad valorem tariffs will apply to specific ones too, as well as to combinations of the two.

Tariffs can be discriminatory or non-discriminatory by source. Any tariff that applies only to the goods of a particular nation or group of nations is a discriminatory tariff. For example, tariffs on Italian shoes, or on Egyptian cotton, would both be discriminatory tariffs. By contrast, a non-discriminatory tariff is one that applies to all goods of a certain category, regardless of their country of origin. Tariffs on shoes, and cotton, regardless of source, would be non-discriminatory tariffs. Early GATT rules, and current WTO rules, generally forbid member countries from explicit discrimination among other members' goods. If a member extends some tariff preference to imports from another member, that same preference must be extended to imports of the same goods from all members. Some major exceptions to this so-called "most favored nation" (MFN) rule have been allowed, though. Some significant regional trading arrangements-such as the European Union-are allowed to offer tariff preferences to member states that are not offered to WTO members outside the union. Some of the original Commonwealth Preferences, giving members of the British Commonwealth special access to the British market, have been preserved by the Lomé Convention even after Britain's entry into the European Union. In addition, the United Nations Conference on Trade and Development (UNCTAD) continues to promote special access for goods from many developing countries into developed countries' markets on special, preferential terms, and this has been accepted into the Development Agenda of the Doha Round.

A protective tariff is one applied to shield a domestic industry from the competition of foreign suppliers. A revenue tariff, by contrast, is one applied purely to raise revenue for the government. Many years ago, a great many tariffs were revenue duties: it was comparatively easy to identify incoming ships, trains, and other vehicles at border crossings and levy the tax. Today, income and other forms of taxation provide by far the largest share of government tax revenues in most developed countries, so the majority of tariffs in those countries are protective duties. In many less-developed countries, though, tariffs remain an important source of government revenue.

\section{Nominal and Effective Rates of Protection}

When domestic production of an import substitute requires the use of imported inputs that are themselves subject to tariffs, the nominal rate of tariff applied to final-good imports may differ quite substantially from the overall extent of protection afforded domestic producers of the import substitute. The effective rate of protection is an estimate of the overall extent to which domestic value added in production is protected by the country's entire tariff structure as it affects the imported final good and all intermediate goods in the production process. Calculating effective rates of protection is a tedious business, and it is often of necessity based on arguable assumptions about the underlying production process. Nonetheless the exercise can be illuminating and can provide policy makers with sobering and important information. It is easy to see, for example, that while tariffs on a final good tend to advantage domestic producers 
of the good, tariffs on their imported inputs essentially serve as taxes on those same producers. It is therefore quite possible that a haphazard or uncoordinated tariff structure-thought to be encouraging domestic producers-may, instead, actually serve to discourage domestic production of that good if the rate of effective protection afforded by the entire tariff structure is negative. Quite apart from the wisdom of implementing those tariffs in the first place, such a situation is, at the very least, usually at odds with the policymakers' intentions.

\section{Tariffs Today}

The post-war drive for broad trade liberalization, starting with the GATT and continuing through the WTO, has led to significant worldwide reduction in tariffs. Table 6.1 reports average rates of tariff, in their ad valorem equivalent, across broad WTO member groupings in 2008. For comparison, earlier figures are included in parenthesis. Over roughly the past two decades, tariff rates have declined very broadly-sometimes

Table 6.1 Tariff rates by WTO member grouping, 2008

\begin{tabular}{|c|c|c|c|c|c|}
\hline & \multicolumn{4}{|c|}{ Average } & \multirow{2}{*}{$\begin{array}{l}\text { Percentage } \\
\text { of lines } \\
\text { greater than } \\
15 \%\end{array}$} \\
\hline & Simple & Weighted & Std. dev. & Max. rate & \\
\hline \multicolumn{6}{|l|}{ High-income Members } \\
\hline Effective Applied Rate & 2.5 & 1.3 & 6.2 & 555 & 2.4 \\
\hline MFN Rate & 3.2 & 2.3 & 7.5 & 555 & 2.7 \\
\hline Preferential & 0.8 & 0.8 & 6.2 & 500 & 0.9 \\
\hline (1988 Effective Applied Rate) & $(4.3)$ & (3.3) & & & \\
\hline \multicolumn{6}{|l|}{ Developing Members } \\
\hline Effective Applied Rate & 7.2 & 4.3 & 20.3 & 3000 & 18.8 \\
\hline MFN Rate & 9.3 & 6.3 & 22.7 & 3000 & 24.9 \\
\hline Preferential & 2.2 & 1.5 & 7.3 & 254 & 6.2 \\
\hline (1988 Effective Applied Rate) & $(18.9)$ & $(16.4)$ & & & \\
\hline \multicolumn{6}{|l|}{ Least-developed Members } \\
\hline Effective Applied Rate & 13.1 & 9.7 & 11.1 & 200 & 54.0 \\
\hline MFN Rate & 13.3 & 10.4 & 9.7 & 200 & 48.1 \\
\hline Preferential & 4.8 & 2.1 & 9.7 & 100 & 29.2 \\
\hline (1989 Effective Applied Rate) & $(105.4)$ & $(88.4)$ & & & \\
\hline
\end{tabular}

Source: UNCTAD TRAINS database at <http://ro.unctad.org/trains_new/index.shtm> 
significantly. However, while rates of tariff are generally lower than they were in the past, there remains considerable diversity across product lines (so-called tariff lines), and across countries. While developing and least developed WTO members have always had higher average rates of tariff, covering a broader range of products, even among developed countries some products continue to be subject to extremely high rates of protection. Hence, a good distance has yet to be traveled in the drive for worldwide trade liberalization.

\section{Tariff Incidence in the Small Country}

To explore the impact of tariffs more closely, we begin with the case of a small country. For our purposes, a country is considered small in the world market for some good, regardless of that country's population or geographic size, if its domestic consumption, domestic production, and imports of the good have only negligible effects on world market conditions, especially the good's price.

Throughout this chapter, we will assume that the domestic markets in our analysis are perfectly competitive, with many small consumers and many competing producers of the same homogeneous good. Even when these are not wholly accurate descriptions of the relevant market structure, assuming competitive markets is a useful simplification that leads us, in many cases, to similar conclusions to those we would reach through application of more complex methods needed to analyze imperfectly competitive markets.

Figure 6.1 depicts domestic market demand and domestic market supply for some good at different market prices. With no access to world markets, the equilibrium market price and the quantity of the good produced and consumed in this small country would be found at the intersection of market demand and market supply. However, in

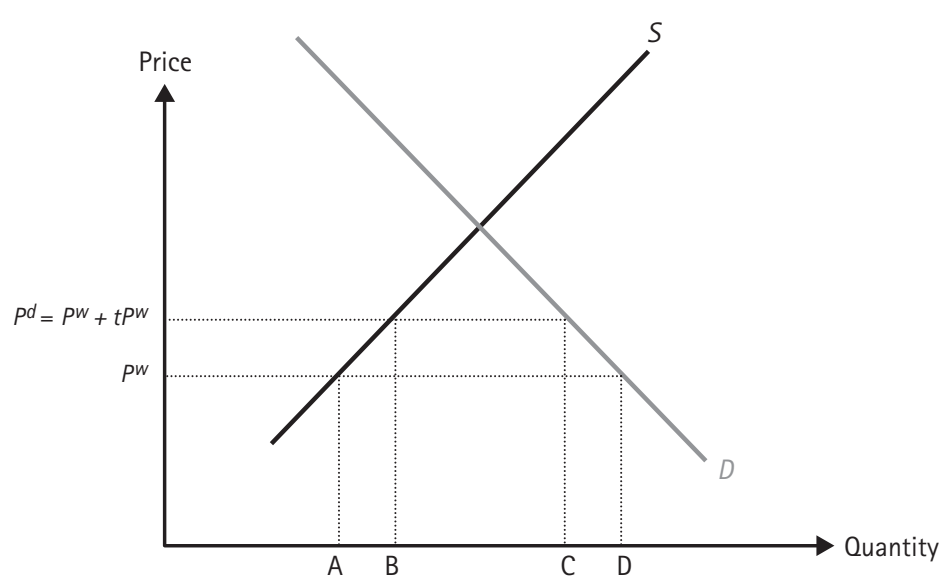

FIGURE 6.1 A tariff's impact on resource allocation. 
a regime of free trade, if buyers and sellers residing in this country have costless access to the larger world market on which this good currently trades at world price $P^{w}$, and if (as we will assume) domestic buyers regard the imported item as indistinguishable from the domestic good, no consumer would be willing to pay more than $P^{w}$ for a unit of this good and, so, no domestic producer could sell above that price. In Figure 6.1, we can see from the domestic market demand curve that, at a price of $P^{w}$, buyers would demand a total of D units. At that same price, we can see from the domestic supply curve that domestic producers would be willing to produce only A units. The difference between domestic demand and domestic supply at $P^{w}$ - the quantity represented by the line segment $\mathrm{AD}-$ measures the quantity of imports. Notice that any good a country imports is necessarily one for which there is excess demand in the domestic market at the prevailing world market price.

\section{How Tariffs Affect Resource Allocation}

If an ad valorem tariff rate of $t>0$ (in decimal form) is imposed on imports of this good, then under this tariff policy a unit of the foreign-produced good, valued on the world market at $P^{w}$, would be subject to import taxes of $t P^{w}$. Initially, buyers in the tariff-imposing country would be faced with a choice: buy a unit of the domestic good for the prevailing price $P^{w}$, or buy a unit of the imported good, which importers could sell for no less than $P^{w}+t P^{w}$ and still break even. Any sensible buyer would want to buy the domestic item at the now-cheaper price.

But what effect would such actions-taken by large numbers of buyers simultaneously-have on market conditions and the allocation of resources in the tariff-imposing country?

Before the tariff was imposed, home-country buyers, in all, were prepared to buy more units of the good at $P^{w}$ than home-country producers were prepared to sell at that price, the difference being made up by imports. But now, as home-country buyers turn away from the costlier import and turn toward the domestic good, they will soon find there is not enough to satisfy all buyers at the prevailing price. This excess demand from domestic buyers will then cause the price of the domestic good, $P^{d}$, to rise above $P^{w}$, as buyers bid against each other for the available quantity. This rise in the domestic price, set off by imposition of the tariff, will then, itself, set in motion powerful market forces affecting both domestic producers and consumers.

As the price they must pay for the domestic good begins to rise, consumers will tend to reduce their purchases, economizing on this increasingly expensive item. This is called the consumption effect of the tariff. At the same time, the rising price of the domestic good makes it now more profitable for domestic producers to increase production in existing plants, to bring new plants into production, and perhaps even for new firms to enter the market. The extent to which the tariff increases domestic production of the import substitute is called the protective effect of the tariff. In Figure 6.1, imposition of this tariff should see the domestic price of the good, $P^{d}$, begin to rise above $P^{w}$. As it does, domestic consumers move up the market demand curve, and the total number of units they demand will begin to decline leftward from $\mathrm{D}$; at the same time, 
however, domestic producers move up the market supply curve and domestic production will increase rightward from A.

Both the decrease in domestic consumption and the increase in domestic production caused by the rise in $P^{d}$ work to reduce excess demand for the domestic good and so, over time, tend to slow the rise in its price. When will that process stop entirely? A moment's thought will convince you that as long as the price of the domestic good, $P^{d}$, is less than the price of the imported item, inclusive of tariff, $P^{w}+t P^{w}$, domestic consumers will continue to turn to domestic sources and, as long as these remain in excess demand in the domestic market, $P^{d}$ will continue to rise. If the tariff were sufficiently high that $P^{w}+t P^{w}$ exceeded the price at which domestic demand and supply intersect in Figure 6.1, then $P^{d}$ would rise to the level of that point of intersection and the total quantity demanded by domestic buyers would be willingly supplied by domestic producers at that price. There would then no longer be pressure on domestic price to rise as all those who wish to buy the good at that price would find a willing domestic supplier. In this scenario, imports would have been completely choked off. A tariff with this effect is called a prohibitive tariff. If, however, the rate of tariff were not prohibitive, and $P^{w}+t P^{w}$ were, say, as indicated on the vertical axis in Figure 6.1, then $P^{d}$ would rise only to that level and no further. Why no further? Because if $P^{d}$ were to rise above $P^{w}+t P^{w}$, domestic buyers would once again find imports cheaper than the domestic good and so switch their purchases back to the imported item. Foreign exporters would be willing to sell at that price, too, since they collect $P^{w}+t P^{w}$ per unit from home country buyers, pay the home country government $\mathrm{t} P^{w}$ in tariff duties, and receive, net, the world price per unit, $P^{w}$. We conclude that, for all but prohibitive tariffs, the domestic price of the protected good must rise by the full extent of the tariff, so that in the post-tariff market equilibrium,

$$
P^{d}=P^{w}+t P^{w}
$$

This is illustrated in Figure 6.1.

Stepping back to compare the pre-tariff equilibrium with the full post-tariff equilibrium, what effects has the decision to implement this non-prohibitive tariff had on the allocation of resources in the tariff-imposing country? Some are seen in Figure 6.1, and we've noted them already: as the price of the domestic good rises, increased domestic production from $\mathrm{A}$ to $\mathrm{B}$ is encouraged, and decreased domestic consumption from $\mathrm{D}$ to $\mathrm{C}$ results. The quantity of imports falls, too, from $\mathrm{AD}$ before the tariff to $\mathrm{BC}$ after. In addition, the government now collects tariff revenue that it did not have before. This is called the revenue effect of the tariff.

But some of the effects of this tariff are unseen. For example, as firms increase output from A to B, additional labor is hired and employment in the protected industry will rise; additional capital, raw materials, and other domestic resources will be drawn into the protected industry too. These resources will have to come from somewhere: to the extent that they are induced away from other productive uses elsewhere in the economy, we can expect that output and employment in those other industries will decline. We 
will not pursue the full implications of these unseen effects right now: but it is wise to keep an awareness of them in the back of the mind.

\section{How Tariffs Affect Peoples' Welfare}

Tariffs cause prices to change, and people are affected as a result. But just how a person is affected depends importantly on who they are. Consumers of the import and the domestic good are generally made worse off by tariffs: they must pay higher prices for the goods they purchase-whether that is the imported item or the domestically produced one. Both will rise in price with the tariff. On the other hand, domestic producers of the good will generally be better off: higher prices for their product, and higher levels of employment and production, usually translate into higher earnings and profit for the firms' owners. The government, too, gains some advantage from the tariff: as long as the tariff does not choke off all imports, the government will have a new source of revenuethe tariff $(\operatorname{tax})$ revenue on the remaining volume of imports.

That tariffs can redistribute welfare in this manner-away from consumers and toward domestic producers and the government-is an important consequence of tariffs and, indeed, may often be the motivating reason a government will decide to impose them. Perhaps the imported good is considered by government to be a frivolous luxury item, only consumed by the idle rich. Then some justification may be felt in imposing the tariff precisely because it redistributes welfare away from those consumers toward others. Perhaps, instead, domestic producers of the good are a favored group: political backers of the regime in power, for example, or perhaps merely just a sympathetic group-poor village women producing simple manufactured or agricultural goods, for example. In such cases, the motivation to impose the tariff may simply be an affirmative desire to help the favored group, with no particular desire to discourage anyone's consumption or harm anyone else. Nonetheless, the tariff will help some and it will harm others-there will be winners and losers. This simple fact should give the policymaker pause to consider the distributional effects of the tariff in their entirety.

\section{What's Wrong with Tariffs}

Granting that there will be winners and losers when a tariff is imposed, what can we say about its welfare effects on the tariff-imposing country "as a whole?" To answer this, we need some way to measure the impact of tariffs on those that are affected, and we need some agreement on how the different costs borne by some and benefits enjoyed by others will be added up, or aggregated, into an overall assessment of the impact on society as a whole. Economists commonly use consumer surplus to measure the welfare effects on consumers, and producer surplus to measure the effects on domestic producers. Consumer and producer surplus measures, and their relation to social welfare, are described in the Annex to this chapter. In the discussion to follow, it is assumed the reader is familiar with that material.

In Figure 6.2, which reproduces the elements of Figure 6.1, the distributional effects of the tariff can be clearly seen. The tariff, causing domestic price of the good to rise from $P^{w}$ to $P^{w}+t P^{w}$, causes consumer welfare, measured by consumer surplus, to fall 


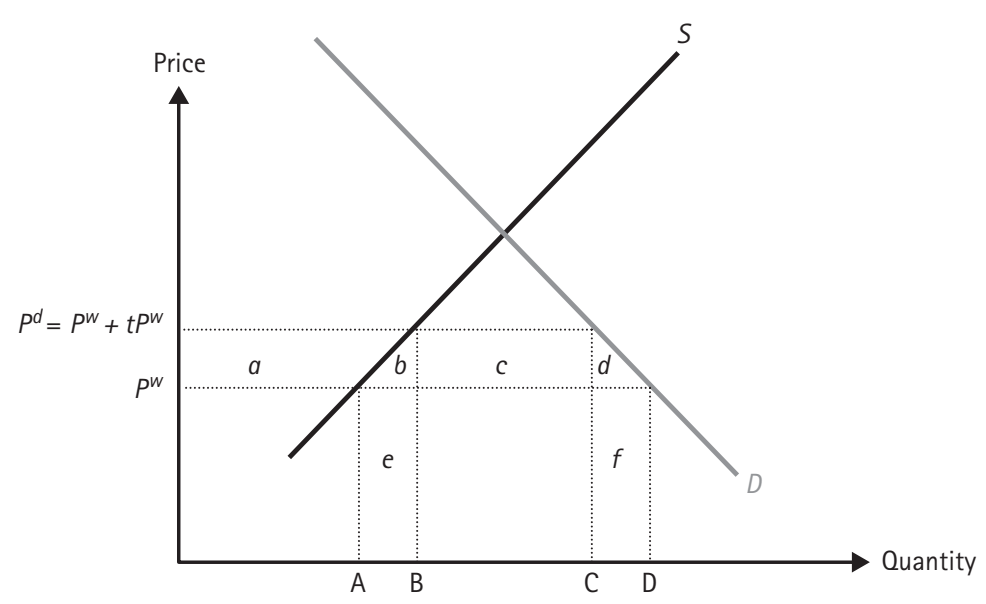

FIGURE 6.2 A tariff's impact on welfare.

by an amount equal to sum of areas $a+b+c+d$. That same price rise, however, causes the welfare of domestic producers, measured by producer surplus, to rise by an amount equal to area $a$. In addition, the government now collects tariff revenue it did not have before, and if we presume that each such dollar is used by the government to benefit someone in society by a dollar, we must also reckon that revenue on the "plus" side of the social ledger. In Figure 6.2, the area marked $c$ measures the full extent of the tariff revenue collected by the government: $t P^{w}$ (the height of box $c$ ) is collected on each of BC units imported (the width of the box $c$ ), giving total tariff revenue equal to the product, $t P^{w}(\mathrm{AB})$.

If we are content to treat a dollar's gain, or loss, to any one person in society as having the same social importance as a dollar's gain or loss to anyone else-a strictly utilitarian criterion of social welfare-then how do the winners' gains and losers' losses all add up? It is easy to see in Figure 6.2 that if consumers lose $a+b+c+d$, while producers gain $a$ and the government gains revenue of $c$, there is still a net loss to society equal to the sum of areas $b+d$. This is called the dead-weight loss due to the tariff-it is welfare that someone in society could be enjoying if it weren't for the tariff-and it measures the magnitude of the net social loss from the tariff that will be borne, period after period, while the tariff is in place.

How, intuitively, can we understand the sources of this net social loss? First, notice that there are two distinct components to it: area $d$ and area $b$. Let's focus on area $d$ first. Recall that one effect of the tariff is to cause consumers to reduce their purchases from $\mathrm{D}$ to $\mathrm{C}$. The total value of those units to consumers-their total willingness to pay for them-is equal to the area under the demand curve, or $d+f$. Before the tariff, those CD units of domestic consumption were imported from the foreigner at $P^{w}$ per unit, or for a total outlay of only $f$. Area $d$, then, measures the net gain consumers were able to enjoy when, before the tariff, they consumed something worth $d+f$ to them while paying only $f$ to have it. With the tariff, that consumption of CD is no more and, so, neither is 
the net benefit someone in society enjoyed from it. Now focus on area $b$. Recall that the other effect of the tariff was to encourage increased production of the domestic good by an additional $\mathrm{AB}$ units. Before the tariff, those $\mathrm{AB}$ units of domestic consumption were, instead, imported from the foreigner for $P^{w}$ per unit, or a total outlay of domestic resources equal to area $\boldsymbol{e}$. Producing those $\mathrm{AB}$ units domestically requires the use of domestic resources-land, labor, capital, and other resources - and those have a dollar value equal to the whole of the area under the supply curve, or $b+e$. Area $b$, then, measures the amount of additional domestic resources now devoted to that bit of domestic consumption over and above what had to be expended before the tariff. Economists call area $d$ the consumption-side inefficiency introduced by the tariff and area $b$ the production-side inefficiency.

We've argued that area $b+d$ must be regarded as a net social loss, "if we are content to treat a dollar's gain, or loss, to any one person in society as having the same social importance as a dollar's gain or loss to anyone else." But what if the policymaker has very good reasons not to hold this view? Suppose, for example, there is a broad social consensus that domestic producers, as a historically disadvantaged group in this society, merit extra weight in the social calculation; that a dollar's gain in welfare to that group should be given greater importance than a dollar's loss in welfare to consumers of this good in the overall social evaluation. Policymakers often have perfectly valid distribution preferences of this sort, and welfare redistribution is a very common objective of government policy. Since tariffs redistribute welfare, why not use them to help achieve those distributional goals whenever possible? The answer is simple: tariffs are an inefficient means of redistributing welfare. Because the dollar value of the welfare loss to consumers is greater than the dollar value of the welfare gain to producers and the government by the amount $b+d$, consumers end up paying that much more than they should have to in order for the government to achieve the goal of transferring welfare in the amount $a+c$. If, instead of implementing a tariff, government were to simply impose a lump-sum tax on consumers equal in total dollar amount to area $a+c$, then transfer that amount to producers and anyone else it favored, the recipients would be just as well off as they were going to be under the tariff policy, but consumers-still able to consume the imported good at $P^{w}$-would suffer a welfare loss of only $a+c$ and so be better off than they would have been under the tariff policy by $b+d$. Because tariffs distort prices faced by consumers and producers they introduce consumption-side and production-side inefficiencies, making the cost of achieving the distributional objective greater than it needs to be. For more discussion of the dead-weight loss and its relation to social welfare, see the Annex to this chapter.

\section{Tariff Incidence in the Large Country}

The analysis of tariffs in the case of a large country is similar to that of a small country, but there are also important differences. Regardless of its geographic size, a country is considered a large country in the world market for some good if its 


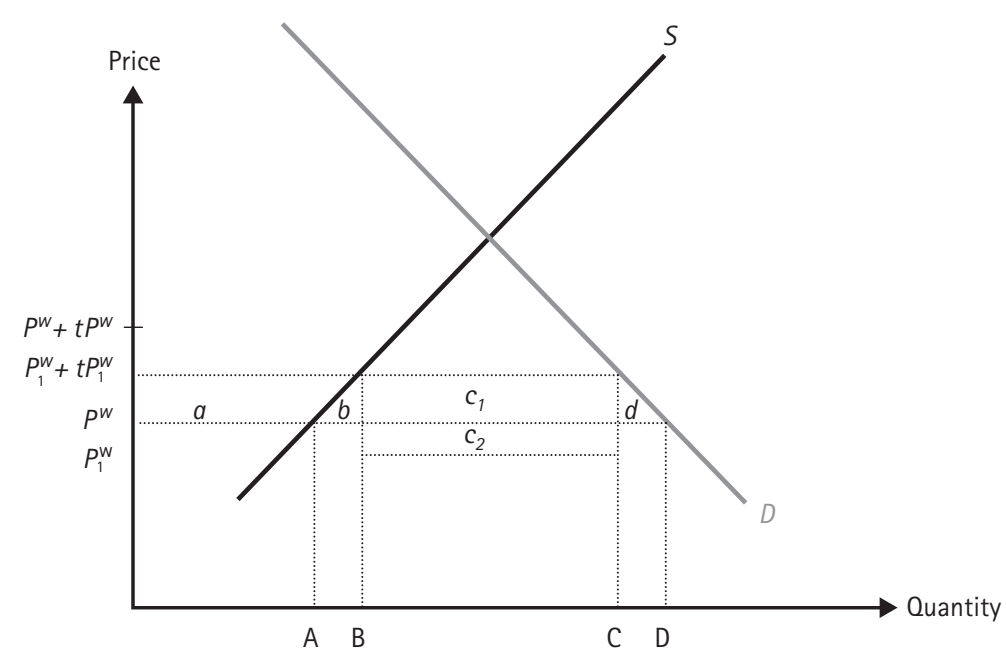

FIGURE 6.3 Tariff incidence in a large country.

domestic consumption, domestic production, and imports of it can have noticeable effects on world market conditions, especially market price.

\section{The Terms of Trade Effect}

As we've seen, tariffs reduce domestic consumption and encourage domestic production, thereby reducing the volume of a country's imports. When those imports are an important component of total world demand for the good, that drop in imports will shift the world demand curve for the good and cause its equilibrium world price to fall. This terms of trade effect can mitigate the adverse effects of the tariff on the tariff-imposing country, essentially by shifting a portion of the burden onto its trading partners.

To see this more clearly, consider Figure 6.3, which depicts domestic market demand and supply for a large-country importer of some good. Under free trade, the initial world price is again $P^{w}$, domestic consumption is at $\mathrm{D}$, domestic production at $\mathrm{A}$, with imports of $\mathrm{AD}$. If an ad valorem tariff of $t>0$ were imposed, and if the fall in this country's imports were to have no effect on world market price, let us suppose that the domestic price of the good would rise to $P^{w}+t P^{w}$. However, if the decrease in import demand from the tariff-imposing country causes world market price for the good to fall to, say, $P_{1}^{w}$, then the domestic price of the good in the tariff-imposing country will only rise to $P_{1}^{w}+t P_{1}^{w}$ before equilibrium is restored with domestic consumption of $\mathrm{C}$, domestic production of $\mathrm{B}$, and imports of $\mathrm{BC}$. As we've seen before, this tariff discourages domestic consumption, encourages domestic production, and reduces the country's volume of imports.

The distributive effects of this tariff are similar to those we've seen in the small country: the increase in domestic price caused by the tariff redistributes welfare from consumers to producers and the government. Here, consumer welfare is again reduced by $a+b+c_{1}+d$, producer welfare again increases by $a$, and government again earns new revenue of $c_{1}+c_{2}$. The tariff again introduces a consumption-side inefficiency of $d$ and 
a production-side inefficiency of $b$, but this time there is no net loss to society. In fact, social welfare increases overall as a result of this tariff! How can that be? Notice that, this time, part of the tariff revenue the government collects-that part of total tariff revenue, labeled $c_{2}$, that lies below the level of the original price $P^{w}$-is, in effect, no new burden for domestic consumers, who only see the price they pay rise from $P^{w}$ to $P_{1}^{w}+t P_{1}^{w}$. Instead, it is a new type of burden being imposed on the country's trading partners. Foreign producers, who previously received $P^{w}$ per unit on those $\mathrm{BC}$ units now receive only $P_{1}^{w}$ . Domestic consumers may pay a total tariff bill equal to the whole of areas $c_{1}+c_{2}$, but only the portion above $P^{w}$ is a new net burden on them: the portion below the level of $P^{w}$ can be regarded as a transfer of welfare from foreign producers, to domestic consumers, and then from domestic consumers to the government. In Figure 6.3, the size of that transfer from the country's trading partners more than offsets the efficiency losses $b+d$, resulting in a net welfare gain for the tariff-imposing country.

\section{The Optimal Tariff}

One should not regard the case we've just described as rare or unusual. Quite often, when a country's import volumes have some impact on the world price, it should be able to craft some tariff that is welfare improving. Of course, policymakers could get it wrong-so this does not mean that just any rate of tariff will raise welfare in the large country. But there will often be at least one rate for which the tariff revenue extracted from the country's trading partners more than compensates for the production-side and consumption-side inefficiencies it causes. Since there may be more than one such rate, the one which maximizes the country's net gain is called the optimal tariff.

By distorting market prices at home and abroad, one country's optimal tariff always introduces consumption-side and production-side inefficiencies into the world economy. And while we've seen that those it causes in the tariff-imposing country itself are more than outweighed by that country's tariff revenue gains, those tariff revenue gains are at the expense of producers somewhere else. The world as a whole must therefore lose when any country imposes an optimal tariff.

But should any one country's policymakers be more concerned about world welfare than they are about their own national welfare? If an optimal tariff can raise your country's welfare, shouldn't you impose one? Doesn't the imperative of advancing the nation's interest compel it?

Perhaps, but it would be wise to think carefully before doing so. Because when the tariff-imposing country gains only at the expense of its trading partners, those trading partners may not just sit idly by. In fact, there may be good reasons for them to retaliate with tariffs of their own.

\section{Retaliation}

When two or more countries' welfare are interdependent-when the actions of any one of them can affect the others, as well as themselves-all the elements of a strategic game are present. In such situations, rational "players" must think carefully about how others are likely to respond to actions they take, and how that, in turn, can affect them. 


$\begin{array}{cccc} & & \text { Country } 2 & \\ & & \text { Free trade } & \text { Optimal tariff } \\ \text { Country } 1 & & & \\ & \text { Free trade } & 100,100 & 80,120 \\ & \text { Optimal tariff } & 120,80 & 90,90\end{array}$

FIGURE 6.4 Tariffs and retaliation.

Figure 6.4 is the payoff matrix for a typical "tariff game" between two large countries. Each country may either elect a regime of free trade, with no tariffs, or it may implement its optimal tariff. We've seen that if one country implements an optimal tariff while its trading partner acquiesces and continues with a policy of free trade, the tariff-imposing country's welfare will rise and that of its trading partner will fall. It is easy to imagine that if, instead, the trading partner were to retaliate and impose an optimal tariff of its own, that country could recoup some of its losses, albeit at the expense of the other country. The entries in the payoff matrix reflect this thinking. The first number in each cell is some index of national welfare in Country 1 , the row player, and the second some index of national welfare in Country 2, the column player.

Let's look carefully at the strategic situation facing each of these countries as they contemplate what their trade policy should be. If Country 1 believes Country 2 will continue to pursue free trade even if Country 1 imposes an optimal tariff, Country 1 can raise its welfare from 100 to 120. If, instead, Country 1 believes that Country 2 will impose its optimal tariff, Country 1 would suffer welfare of only 80 if it adhered to free trade. But it could recoup some of its loss, and have welfare of 90 , if, instead, it retaliated with an optimal tariff of its own. Notice that no matter what Country 1 thinks Country 2 will do, its own best course of action is always the same: it should impose an optimal tariff! Of course, the same is true of Country 2: no matter what it thinks Country 1 will do, its own best course of action is always to impose an optimal tariff too. Game theorists would say imposing an optimal tariff is a strictly dominant strategy for each of these countries because no matter what the other player does, that strategy is always the player's very best course of action. Rational players, when they have them, can be expected to use their strictly dominant strategies, so the outcome of this game seems easy to predict: each country will impose an optimal tariff and each will receive welfare of 90 .

But notice something interesting about this outcome: both countries are worse off than they would be if they had both resisted the temptation and stayed with a policy of free trade: each would have then had welfare of 100, instead of only 90. Recognizing this, rational players should then, instead, elect free trade, right? They would both be better off if they did. But if either one in fact elects free trade, the other can do even better by imposing an optimal tariff, getting welfare of 120! If either thinks its rival might just do such a thing, it is better off protecting itself with its own optimal tariff, getting welfare of 90 , rather than suffering 80 . But if they both think and act this way, the outcome is, again, that each imposes an optimal tariff on the other and both are again worse off than they would be if they had both elected free trade! This sorry state of affairs is called a 
Prisoner's Dilemma: while there may be mutual gains to be had by cooperating to support a regime of free trade, the logic of national interest makes those gains seemingly impossible to attain.

Difficult, perhaps, but not impossible. One way around this Prisoners Dilemma would be to change the payoffs countries see in the choice between free trade and protection. Indeed, one can regard much of the post-war effort to create institutions such as the GATT and WTO, and to write the rules for membership in them, as an effort to do just that. Negotiations that result in mutually agreed upon rules and sanction regimes are often able to modify the structure of incentives from those so starkly apparent here, by increasing the gains from cooperation and reducing the gains from unilateral action. In so doing, they hope to align the incentives of individual member countries to find it more in their national interest to play their part in the cooperative outcome with benefits for all.

\section{IMPORT QUOTAS}

A quota is a quantitative restriction on trade. Under an import quota, the government sets an upper limit on the quantity of some good that may be imported in a given period-say, a limit of 40 tons of wheat per year. With a quota, no tax is collected on imports directly, as with a tariff. However, the quota will have very similar effects as a tariff does on resource allocation and the distribution of welfare. But there are a few key differences, too.

\section{How Quotas Affect Resource Allocation and Welfare}

The domestic market for an imported good is depicted in Figure 6.5. Under free trade, imports are available on the world market at $P^{w}$ and this small country imports the quantity $\mathrm{AD}$. Now suppose the government implements a quota on imports, mandating that no more than $\mathrm{BC}<\mathrm{AD}$ units be admitted. Because domestic consumers demand $\mathrm{D}$ units at the free trade price $P^{w}$, while domestic producers provide only A at that price, once imports are restricted to something less than $\mathrm{AD}$, there will be excess domestic demand for the good at the world price $P^{w}$. The domestic price will therefore begin to rise above $P^{w}$ as frustrated buyers begin trying to outbid one another for the available quantity. As the domestic price begins to rise, domestic producers will increase production and domestic consumers will reduce their consumption. Price will continue to rise until the total quantity demanded by consumers at the prevailing price is matched by the quantity domestic producers are willing to supply at that price, plus imports of no more than BC, as is the case at $P^{d}$.

Through these indirect effects on domestic price, a quota, like a tariff, encourages increased production of the import substitute, and draws additional resources of land, labor, and capital into the protected sector, as domestic producers respond to the 


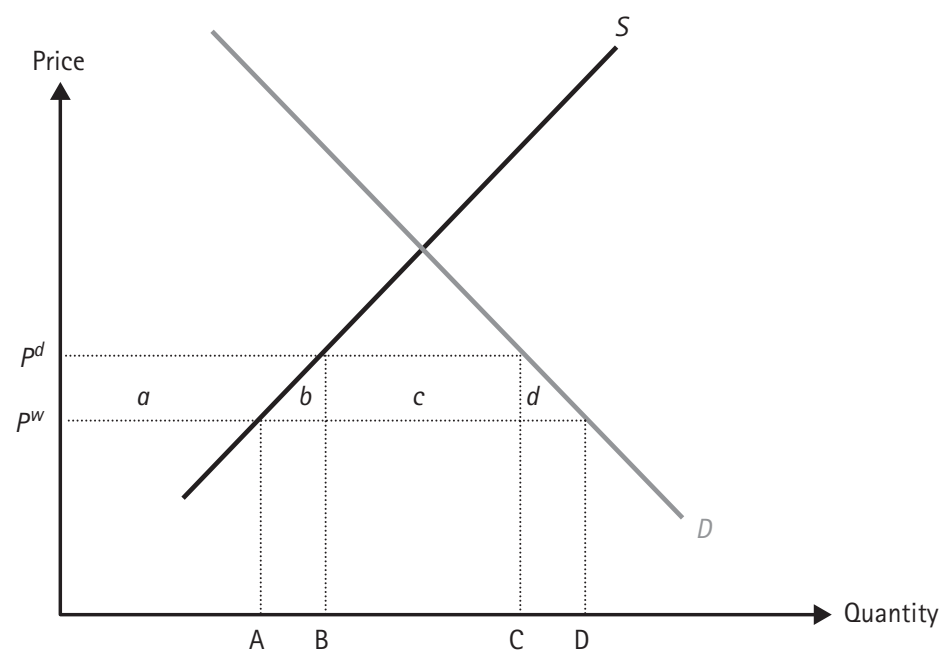

FIGURE 6.5 A quota's impact on resource allocation and welfare.

good's rising price. Here, the protective effect of the quota is AB. There is a consumption effect, too, as consumers also respond to the good's rising price, reducing their total purchases by CD.

It is easy to see in Figure 6.5 that the quota of BC units ultimately has exactly the same effects on domestic production, domestic consumption, and the allocation of resources to the protected sector as would an appropriate ad valorem tariff. Specifically, a tariff rate of $\left(P^{d}-P^{w}\right) / P^{w}$ would raise domestic price to $P^{w}+\left(\left(P^{d}-P^{w}\right) / P^{w}\right) P^{w}=P^{d}$, giving precisely the same ultimate effects on production and consumption. In this sense, there is said to be tariff and quota equivalence in the ultimate effects each of them has on the allocation of resources.

\section{Tariff and Quota Equivalence?}

The rise in price following imposition of the quota redistributes welfare, too, very much like a tariff. But there are some important differences.

As price rises from $P^{w}$ to $P^{d}$, consumer surplus falls by $a+b+c+d$, while producer surplus rises by $a$. Putting aside for the moment what we should make of area $c$, there will again be net national welfare losses of $b$ and $d$, as there were with the tariff, because quotas introduce the same sort of production-side and consumption-side inefficiencies as tariffs do.

Under a tariff, that part of the loss that is consumer surplus measured by area $c$ was compensated for by an equal increase in tariff revenue collected by government. With a quota, the government does not collect any tax revenue of this sort. Instead, it allocates rights to import-import licenses-and how those rights are allocated directly affects the distribution of welfare. 
Suppose, for example, that the government simply awards a license to import one unit of this good to some importer. That individual could purchase one unit of the good abroad at the world price $P^{w}$, import it into the country and sell it at the prevailing domestic price $P^{d}$, earning a profit-or, more precisely-an economic rent-equal to $P^{d}-P^{w}$. If licenses for a total of $\mathrm{BC}$ units are simply given to importers-say in proportion to the quantities each imported before the quota was imposed-then total rents earned by all importers so favored would be equal in amount to area $c$. In this scenario, the quota redistributes welfare from consumers to domestic producers and to those lucky enough to secure import licenses at no cost.

But why should government simply give away such a valuable item? If, instead, it were to auction off those import licenses, importers, and others, would have an incentive to bid for them. Since each unit of the good purchased abroad and then sold on the domestic market under the quota regime would earn economic rent of $P^{d}-P^{w}$, bidders would bid up to precisely that amount in order to obtain the right to import a unit. If the rights to $\mathrm{BC}$ units were auctioned for their full value to bidders, the government could earn revenue from the sale of the full set of licenses equal in amount to the whole of area $a$ ! Under this method of allocating import licenses, the distributional, as well as the allocative, effects of the quota are fully equivalent to those of an appropriate ad valorem tariff: the quota redistributes welfare from consumers to domestic producers and the government, with a net reduction in national welfare overall due to the production-side and consumption-side inefficiencies caused by the quota.

There are others ways in which tariffs and quotas are not entirely "equivalent." For one, the protective effect of a non-prohibitive ad valorem tariff remains unchanged as changing economic conditions in the tariff-imposing country affect domestic demand

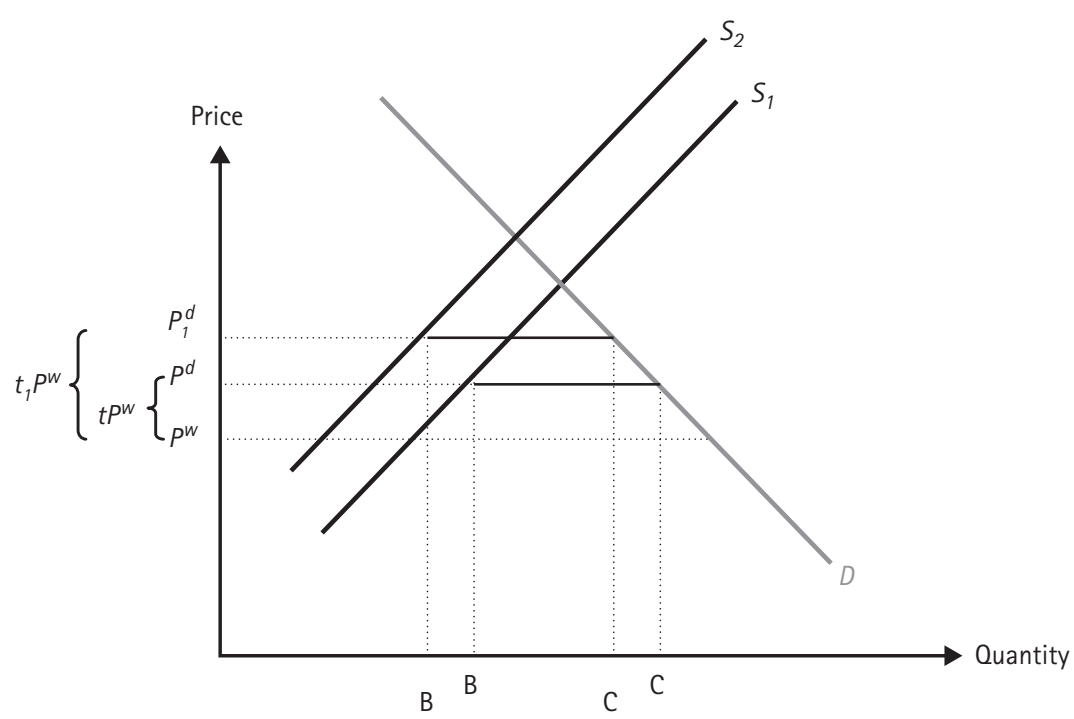

FIGURE 6.6 Quota incidence with shifting supply. 
and/or supply of the protected good-and this is not so with quotas. The de facto rate of protection under a quota will usually change whenever domestic demand and/or domestic supply of the good change. Figure 6.6 illustrates the point. There, a given quota restriction in the amount $\mathrm{BC}$ has a de facto rate of protection equal to an ad valorem tariff of $t$ when domestic market supply is $S_{1}$. If supply shifts to $S_{2}$-due, say, to an increase in input prices, bad weather or some other supply-side shock - the domestic price of the protected good will rise further-this time to $P_{1}^{d}$ - giving a de facto rate of protection equal to that of a larger ad valorem tariff, $t_{1}>t$. Finally, though we will not explore the issue in detail here, we should also note that tariffs and quotas may have quite different effects when the domestic market is not perfectly competitive. For example, when a domestic monopoly produces the import substitute, a tariff forces that firm to act much like a competitive firm in the larger world market, but when a quota is used, the domestic monopoly remains free to exercise its monopoly power over whatever is left to it of the domestic market after the quota.

\section{EXPORTS}

Until now we've focused on policies directed at imports. Policymakers can, and do, implement policies that affect the country's exports as well. In the United States, Article 1, Section 9 of the Constitution contains an explicit prohibition against export duties of any kind, but many other countries employ them. Russia taxes its petroleum exports and Indonesia taxes its palm oil exports. Export subsidies, particularly agricultural export subsidies, have been contentious issues in trade relations between the US and EU, and between developed and developing countries more broadly. The analysis of export taxes and export subsidies, formally very similar to that of tariffs, is often a bit less easily grasped right at first, so we will proceed carefully. Like tariffs, export taxes and export subsidies can be ad valorem, specific or both. Each will have an ad valorem equivalent, however, so we'll treat all cases with a close look at the impact of ad valorem export taxes and ad valorem export subsidies alone.

\section{Export Taxes}

Figure 6.7 depicts domestic demand and supply in the market for some exportable good in a small country. In the absence of any opportunity to trade with others, the domestic market clearing price would be at the intersection of market demand and supply, well below the world price, $P^{w}$. Under free trade, this country would therefore export the good. At the world price $P^{w}$, domestic producers want to sell $\mathrm{D}$ units while at that same price domestic consumers only want to purchase A. Domestic producers will find willing buyers abroad, however, and in the free trade equilibrium exports total $\mathrm{AD}$ units. 


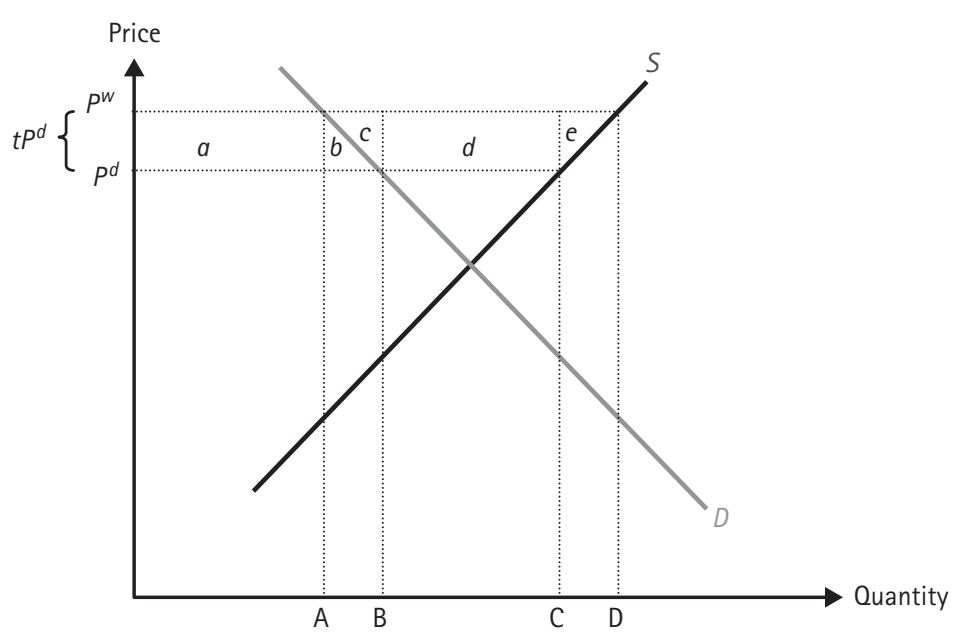

FIGURE 6.7 Incidence of an export tariff.

Following imposition of an ad valorem export tariff ( $\operatorname{tax}$ ) of $t>0$, domestic producers of the exportable good are faced with a choice: they can ship the good abroad and pay a tax on it, or they can sell it in the domestic market tax-free. At first, the choice is simple: if the good is selling at the same price in the domestic market and in the export market, net receipts would be lower for sales abroad by the amount of the tax, so firms will tend to ship fewer units abroad and shift their sales to the domestic market. As many firms act in this way, the quantity of output redirected toward the domestic market will cause the domestic price of the good to fall. That this must happen is clear, once we recall that the good was originally in excess supply domestically: at the world price $P^{w}$, domestic buyers were unwilling to buy all that domestic producers wanted to sell at that price. After imposition of the export tax, then, increased domestic sales by firms seeking to avoid the tax on their exports must force down the domestic price of the good. But just how far will the domestic price, $P^{d}$, fall? If it were to fall far enough, it would at some point become profitable for producers to go ahead and pay the tax on exports if they can earn the higher world price, $P^{w}$, on those sales. Specifically, if $P^{d}>P^{w}-t P^{d}$ the firm earns more on a unit sold at home than it would on a unit taxed upon export at its domestic value, $P^{d}$, and sold abroad at the world price $P^{w}$. Hence, the firm would sell that additional unit at home, putting greater downward pressure on $P^{d}$. By contrast, if $P^{d}<P^{w}-t P^{d}$, the firm earns more by redirecting that unit abroad, earning more, post-tax, than it would from domestic sales, putting upward pressure on $P^{d}$. We may conclude, therefore, that pressure for the domestic price to change will cease only when neither such situation is present: that is, only when $P^{d}=P^{w}-t P^{d}$. This can be rearranged and expressed, instead, as follows:

$$
P^{d}+t P^{d}=P^{w}
$$


Equation (6.2) tells us that the export tax must cause the domestic price of the good to fall by the full extent of that ad valorem tax. That is the situation depicted in Figure 6.7.

It is easy now to see the impact the export tax has on resource allocation in the exporting country. As the domestic price falls following imposition of the tax, domestic consumers increase consumption from A to B units. At the same time, domestic producers reduce production from $\mathrm{D}$ to $\mathrm{C}$, releasing resources of labor, land, and capital. In the post-tax equilibrium, the country's exports have declined from $\mathrm{AD}$ to $\mathrm{BC}$. The government collects tax revenue from the export tariff of $t P^{d}(\mathrm{BC})$, an amount equal to the area marked $d$.

The distributional effects of the export tax are easily seen in Figure 6.7, too. With reduced production at lower prices, domestic producers of the exportable lose producer surplus of $a+b+c+d+e$. With greater consumption at a lower price, consumers gain consumer surplus of $a+b$. As we've noted, the government gains new revenue of $d$. The export tariff, then, redistributes welfare from domestic producers to domestic consumers and the government. But notice that producers' losses are not fully offset by these countervailing social gains: there is a net social loss of $c+e$. We may understand the net national welfare loss as arising from two sources: the redirection of firms' sales from exports toward the domestic market, and the reduction in total production caused by the tax.

We've seen that the price decrease causes domestic consumption to rise by $\mathrm{AB}$ units. Originally, domestic firms were able to sell those units to foreign buyers for $b+c$ in revenue more than they now fetch from domestic buyers. All of that revenue loss cannot be reckoned a social loss, however, because domestic consumers now have $\mathrm{AB}$ units more consumption, on which they enjoy new consumer surplus of $b$. Only $c$, then, can be regarded as a net social loss from the redirection of sales away from exports and toward the domestic market.

We've also seen that the price decrease causes domestic production to fall by CD units overall. Under free trade, firms earned gross revenue on those units equal to the entire area of the rectangle with base CD and height $P^{w}$. The value of society's resources devoted to that amount of production-the land labor and capital used by exporting firms - totaled an amount equal to the area beneath the market supply curve above CD. With the export tax, the firms' lost revenue on those units exceeds the value of the resources that were used to produce them by an amount equal to area $\boldsymbol{e}$, and so that must be reckoned a net loss to society from the overall reduction in output.

\section{Export Subsidies}

Everyone knows that if you tax something, you'll get less of it; and if you subsidize it you'll get more of it. The same is true of exports. But exports are not the only thing affected when government decides to subsidize them. 


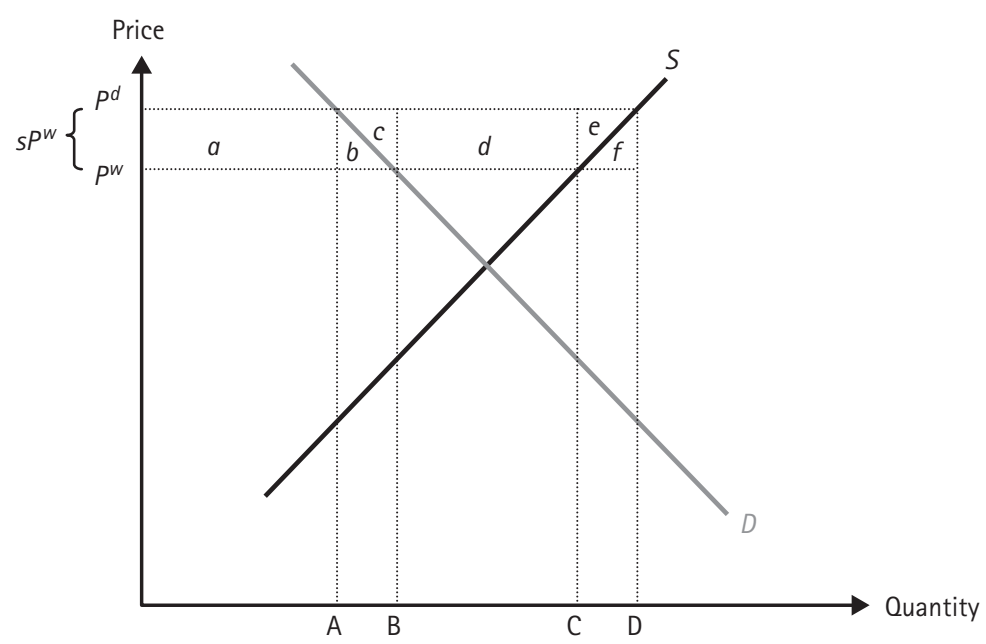

FIGURE 6.8 Incidence of an export subsidy.

Figure 6.8 depicts the domestic market for an exportable good. With free trade at a world price of $P^{w}$, domestic production is at $\mathrm{C}$, domestic consumption at $\mathrm{B}$ and exports are BC.

If an ad valorem subsidy of $s>0$ is granted to exports, domestic producers are faced with a choice: they can ship the good abroad and receive a subsidy on it, or they can sell in the domestic market at the prevailing market price and forego the subsidy. Once again, the choice is simple at first: if the good is selling at the same price in the domestic market and in the export market, net receipts would be higher for sales abroad by the amount of the subsidy, so firms will tend to ship more units abroad and shift sales away from the domestic market. As output is redirected toward the export market, the domestic price of the good must begin to rise as home-country buyers who want the good must be willing to pay what sellers can earn, instead, by exporting: if $P^{d}<P^{w}+s P^{w}$, no firm will sell to a domestic buyer so, in the end, equilibrium in the domestic market will only be restored when

$$
P^{d}=P^{w}+s P^{w}
$$

Equation (6.3) tells us that an export subsidy must cause the domestic price of the good to rise by the full extent of that ad valorem subsidy. That is the situation depicted in Figure 6.8.

As the domestic price of the exportable rises following imposition of the subsidy, domestic consumers reduce consumption from B to A units, while domestic producers increase production from $\mathrm{C}$ to $\mathrm{D}$, drawing more domestic resources of labor, land, and capital into the production of the exportable good. In the post-subsidy equilibrium, exports will rise from $\mathrm{BC}$ to $\mathrm{AD}$ and the government must make subsidy payments of $s P^{w}(\mathrm{AD})$, an amount equal to the sum of areas $b+c+d+e+f$. 
The distributional effects of an export subsidy are exactly opposite to those of the export tax. With increased production at a higher price, domestic producers of the exportable gain producer surplus of $a+b+c+d+e$. With lower consumption at a higher price, consumers lose consumer surplus of $a+b$. To support this policy, the government must commit revenue equal to $b+c+d+e+f$ to pay firms the subsidy. The export subsidy, then, redistributes welfare away from domestic consumers and the government toward domestic producers of the exportable good. But notice that the losses to consumers and the government are greater than the gains to domestic producers: there is, this time, a net social loss equal to $b+f$. Once again, that net social loss arises from two sources: the firms' sales redirected away from the domestic market and toward exports, and the increase in total production encouraged by the subsidy.

We've seen that the price increase causes domestic consumption to decline by $\mathrm{AB}$ units. Originally, consumers were able to buy those from domestic producers at $P^{w}$ and enjoy a consumer surplus of $b$ on them. That is lost with imposition of the export subsidy and, instead, those $\mathrm{AB}$ units are now exported, giving a net social welfare loss equal to $b$ on those units.

That same price increase induces firms to increase total production for export by CD units, on which the government pays a subsidy of $e+f$ to domestic firms. Only area $e$ of that, though, is received as new producer surplus by the firms: the remainder, area $f$, therefore represents a net loss to society.

\section{The Lerner Symmetry Theorem}

To this point, we have tended to focus on the impact of policy in one market. Economists call that a partial equilibrium perspective. But economies are complex networks of interconnected and interdependent markets. It is rarely the case that some impact felt in one market will fail to have repercussions in others. A general equilibrium, or economy-wide, perspective would consider all the ramifications in all directly and indirectly affected markets whenever a policy is implemented.

As it turns out, a full general equilibrium analysis of the policies we've considered so far would not, in the end, cause us to change the basic conclusions of our partial equilibrium analysis. We can be grateful for this because forging that general equilibrium analysis would require a heavy investment in additional analytical machinery with few new insights for the effort. But there is one important exception.

\section{An Economy-Wide Perspective}

No economy has unlimited resources. In fact, it is precisely because a country's resources are limited, while needs and wants are not, that individuals, firms, and governments must make choices about how to use the country's resources. A production possibility frontier (PPF), like that depicted in Figure 6.9, illustrates the type of 


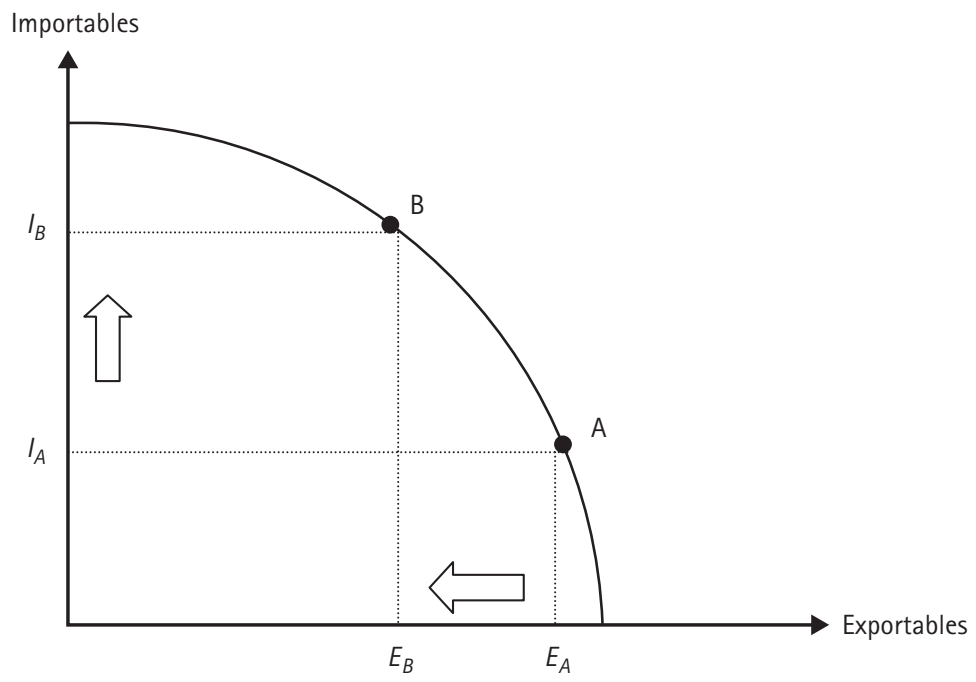

FIGURE 6.9 Lerner Symmetry Theorem and the PPF.

trade-off that must be made when resources are limited. On the horizontal axis, different quantities of exportable goods the country can produce are given. On the vertical axis are different amounts of importables it could also produce at home. Points like $\mathrm{A}$ and $\mathrm{B}$ that lie along the frontier indicate the greatest quantity of importables the economy can produce if it is also going to produce the corresponding amount of exportables, given available technology and the economy's limited resources of labor, land, and capital.

The PPF in Figure 6.9 illustrates an important fact of economic life, and a basic consequence of scarcity: if a country is going to produce more of one thing it must necessarily produce less of something else. Imagine a movement along this country's PPF from A to B. If production of importables rises from $I_{A}$ to $I_{B}$, some of society's resources will have to be directed away from producing exportables, causing the production of those to fall from $E_{A}$ to $E_{B}$.

Now with a moment's reflection, you will recall that import tariffs cause domestic production of importables to rise. In the world of Figure 6.9, such a policy must therefore also cause domestic production of exportables to decline! But then another thought occurs: export taxes cause domestic production of exportables to decline. In the world of Figure 6.9, the resources thereby released must eventually cause the production of importables to rise!

But the "symmetry" actually goes much deeper than this.

Rational consumers and producers throughout the economy make their decisions about how much to buy and sell, respectively, according to the prices they face. In a market economy, resources will therefore be allocated between alternative uses according to relative prices. If the price of one good rises relative to the price of another, consumers 
will buy less of the former and more of the latter. As consumers shift their purchases, producers will produce more of the one good to meet that rising demand and less of the other facing declining demand. Hand in hand, as spending patterns change and production patterns change, some of the economy's resources of land, labor, and capital are systematically redirected from one use to another. Any given set of relative prices is therefore associated with some particular allocation of society's resources among their alternative uses.

In equation (6.1) we noted that an ad valorem tariff of $t$ on importables will cause the domestic and world market prices to differ by the full extent of the tariff. If we let $P_{I}^{d}$ and $P_{l}^{w}$ stand for the domestic and world prices of importables, respectively, we can re-write this relationship as follows:

$$
P_{I}^{d}=P_{I}^{w}+t P_{I}^{w}=P_{I}^{w}(1+t)
$$

In the absence of any taxes or subsidies on exports, the domestic price and world price of exportables would be the same. If $P_{E}$ represents that common price, the relative price of importables in the tariff-imposing country's home market would be

$$
\left(\frac{P_{1}}{P_{E}}\right)^{d}=\left(\frac{P_{I}}{P_{E}}\right)^{w}(1+t)
$$

But suppose, instead, the country were to impose an ad valorem export tax of $t$, instead of a tariff on imports. In equation (6.2) we observed that the domestic price of exportables would ultimately differ by the full extent of the tax. If we let $P_{E}^{d}$ and $P_{E}^{w}$ be the domestic and world prices of exportables, respectively, we can rewrite this relationship as follows:

$$
P_{E}^{d}+t P_{E}^{d}=P_{E}^{w}
$$

or

$$
P_{E}^{d}(1+t)=P_{E}^{w}
$$

or

$$
P_{E}^{d}=P_{E}^{w}\left(\frac{1}{1+t}\right) .
$$

Because there is no tariff on imports, the domestic price and world price of importables would be the same, so if $P_{l}$ represents that common price, the relative price of exportables in the country's home market would be

$$
\left(\frac{P_{E}}{P_{I}}\right)^{d}=\left(\frac{P_{E}}{P_{I}}\right)^{w}\left(\frac{1}{1+t}\right) .
$$


This same expression can be written more usefully if we simply take the reciprocal of each side and rewrite it this way:

$$
\left(\frac{P_{I}}{P_{E}}\right)^{d}=\left(\frac{P_{I}}{P_{E}}\right)^{w}(1+t) .
$$

Notice that equation (6.5) and equation (6.4) are exactly the same!

This is the Lerner Symmetry Theorem: If we take a long-run, economy-wide perspective, we will eventually see that an ad valorem tariff on importables at the rate $t$ will have exactly the same effect on the relative prices of importables and exportables as will an ad valorem export tax at the same rate. Since relative prices govern production, consumption, and the overall allocation of resources in the economy, the implications of this theorem are clear: an import tariff and an export tax will have exactly the same effects on the overall allocation of resources within the country adopting them.

\section{Anti-export Effects of Tariff Protection}

The Lerner Symmetry Theorem encourages policymakers to think broadly about the economy-wide implications of their actions, and it raises awareness of some unintended consequences of actions they might take.

For example, suppose the PPF in Figure 6.9 is that of a country planning to pursue an export-led program of growth and development. If, at the same time, it protects its domestic producers of importables with an import tariff, it will clearly be working against its own plan. The import tariff, raising the domestic relative price of importables, and so encouraging resources to flow into greater production of importables, must also, at the same time, lower the domestic relative price of exportables, causing resources to be drawn away from that sector, and output to fall. These anti-export effects of tariff protection must be taken into consideration in any full assessment of the consequences of tariff protection.

\section{Tariff Preferences for Developing COUNTRIES}

Developing countries have long sought access to developed-country markets on preferential terms, and WTO rules accept the principle of enhanced market access-so called "special and differential treatment" for developing country exports-as an important tool of growth and development. In 2001, the European Union, in its "Anything But Arms" initiative, amended its Generalized Scheme of Preferences to grant duty free and 
quota free access into EU markets of all products, except arms and ammunition, originating in 48 less-developed countries.

To illustrate the impact such policies have on developing and developed countries, consider Figure 6.10, depicting market demand and market supply in a developing country's domestic market for one of its exportable goods. In the absence of any special access, this country's exports will be sold at the world price, $P^{w}$. Domestic consumption will be at $\mathrm{B}$, production at $\mathrm{C}$ and the volume of exports will be $\mathrm{BC}$.

Let us suppose that some developed countryinitially maintains a non-discriminatory ad valorem tariff at the rate $t$ on trade with the rest of the world, and that, therefore, the prevailing domestic price of this good in the developed country's home market is $P^{w}+t P^{w}$. If special, tariff-free access to this country's protected home market is now granted to the developing country depicted in Figure 6.10, exporters there, now able to earn a higher price on sales in the developed country, will redirect sales away from the world market, and away from the domestic market, toward that developed country. As a result, the domestic price of the exportable good in the developing country will rise to the level of market price in the protected, developed country's market, $P^{w}+t P^{w}$. As price rises in the developing country, domestic consumption declines from $\mathrm{B}$ to $\mathrm{A}$, domestic production increases from $\mathrm{C}$ to $\mathrm{D}$, and exports expand from $\mathrm{BC}$ to $\mathrm{AD}$.

The allocative effects in the developing country of enhanced access for their exports to protected developed country markets are exactly the same as those resulting from an export subsidy. The distributional effects-both gross and net-are different however.

With preferential access, producers of the developing country's exportable are made better off: their producer surplus rises by $a+b+c+d+e$. Consumers in the developing country are made worse off: their consumer surplus falls by $a+b$. With an export subsidy, the developing country's government would have had to make subsidy payments

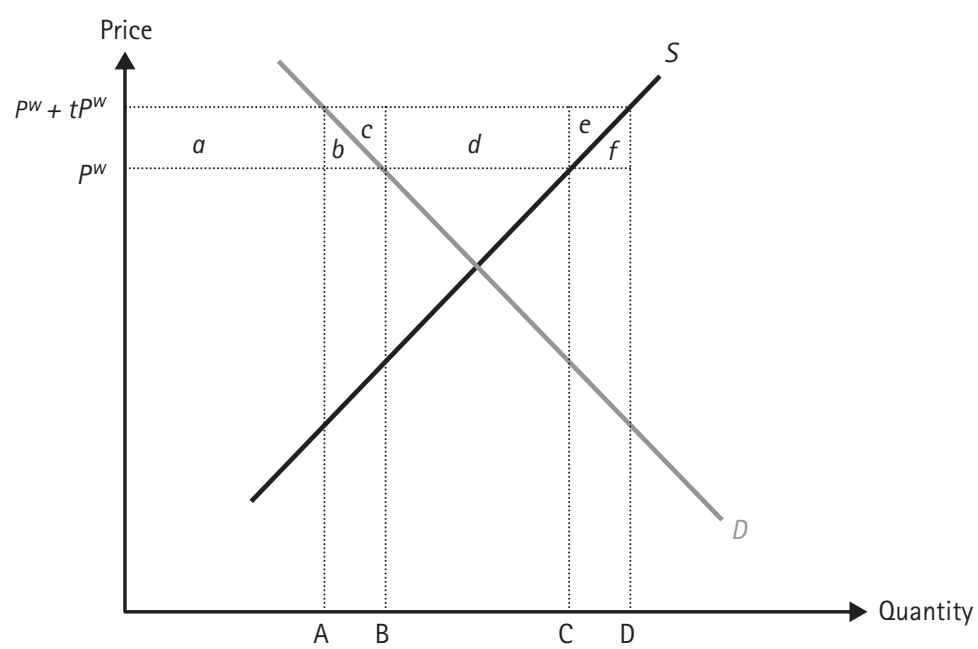

FIGURE 6.10 Tariff preference to a developing country. 
of $b+c+d+e+f$ to have the same allocative effects, and we noted before that that would mean net losses in overall social welfare for the developing country totaling $b+f$. But with preferential access, the developing country government makes no such subsidy payments. Instead, the whole of $b+c+d+e+f$ represents a transfer from consumers in the developed country to producers in the developing country. This more than compensates for the consumption-side inefficiency, $b$, and the production side inefficiency, $f$, giving a net welfare gain in the developing country of $c+d+e$.

Notice, though, that the net welfare gain in the developing country-c $+d+e-$ is smaller than the transfer from developed country consumers $-b+c+d+e+f$. This suggests that direct aid, say in the form of a transfer payment from the developed country government in the amount $c+d+e$, could provide the same net increase in developing country welfare at lower cost to the developed country, and without introducing the production-side and consumption-side inefficiencies that attend the practice of enhanced access. Of course, broader policy issues often arise in the debate on "trade vs. aid," and while these are outside the scope of the present chapter, they will be taken up in more detail in others.

\section{Production Subsidies}

We've seen that tariffs, quotas, export taxes, and export subsidies will always redistribute welfare among producers, consumers, and the government, and will in most cases also give rise to a net dead-weight loss in social welfare, at least in the small country. But tariffs help spur increased domestic production of import substitutes, and that may form part of an overall development plan. Export subsidies encourage increased production of exportables, and that, too, may be part of an overall development plan. However, subsidies to production, rather than taxes or subsidies to trade, will generally be able to achieve the intended objective at lower social cost.

To see why, consider first the left-hand panel of Figure 6.11, and suppose that the objective of policy is to increase domestic production of this importable good from A to B. One way of doing so would be to implement a tariff sufficient to cause the domestic price of the good to rise to $P^{d}$. As we've seen, such a policy would redistribute welfare away from consumers toward producers and the government, but it would also result in an overall deadweight loss in social welfare equal to the sum of areas $b$ and $d$, due, respectively, to the production-side and consumption-side inefficiencies the tariff introduces.

But suppose, instead, the government were to offer a direct per unit subsidy to domestic producers of this good sufficient to shift the market supply curve out (or down) to $S_{s}$. At the world price $P_{w}$, plus a per unit subsidy, domestic producers would find it in their interest to increase production from A to B. That additional production absorbs additional domestic resources worth an amount equal to the area beneath the original market supply curve between A and B. Because those same AB units could have been 

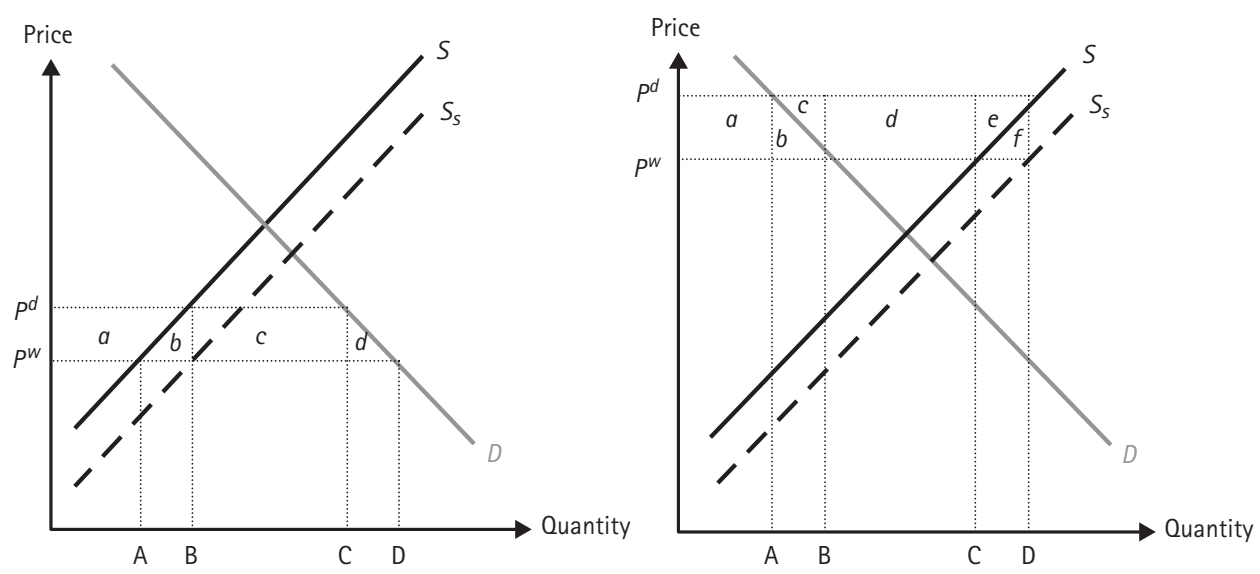

FIGURE 6.11 The Bhagwati-Ramaswami Rule.

purchased from abroad in exchange for domestic resources totaling only the area of the rectangle with base $\mathrm{AB}$ and height $P_{w}$ there is still a production-side welfare loss equal to area $b$. But the policy of subsidizing production has no effect on the price consumers pay-they continue to pay the world price $P_{w}$ and consumption remains at D. As a result, there is no consumption-side loss. Assuming that the subsidy is financed by a non-distorting lump-sum tax on consumers (or anyone else), the overall effect of the subsidy policy is to achieve the same production objective as the tariff, but without the consumption-side cost.

A similar analysis applies in comparing export subsidies with subsidies to the production of exportables, regardless of whether they are sold at home or abroad. In the right-hand panel of Figure 6.11, the world price of some exportable good is $P^{w}$, domestic production is at $\mathrm{C}$, domestic consumption at $\mathrm{B}$, and exports are $\mathrm{BC}$. If the government wanted to encourage production of this exportable good, it could implement an export subsidy that would have the effect of causing the domestic price to rise to $P^{d}$. We've seen that such a policy redistributes welfare from consumers and the government toward producers, but results in a net loss in social welfare equal to the sum of areas $b$ and $f$, due, again, to the consumption-side and production-side inefficiencies, respectively, that this type of policy introduces.

But suppose, instead, the government were to offer a direct per unit subsidy to domestic producers, regardless of whether they sold in the domestic market or abroad. If the subsidy were sufficient to shift the market supply curve out (or down) to $S_{s}$, then at the prevailing world price $P^{w}$, plus a per unit subsidy, domestic producers would find it in their interest to increase production from $\mathrm{C}$ to $\mathrm{D}$. That additional production absorbs additional domestic resources worth an amount equal to the area beneath the original market supply curve between C and D. Domestic producers sell those CD units abroad at $P^{w}$, earning revenues equal only to the area of the rectangle with base $\mathrm{CD}$ and height $P^{w}$, so there is still a production-side welfare loss equal to area $f$. But the policy of subsidizing production again has no effect on the price consumers pay-they continue to pay the 
world price $P^{w}$, and consumption remains at $\mathrm{B}$. As a result, there is no consumption-side loss. Again assuming that the subsidy is financed by a non-distorting lump-sum tax on consumers (or anyone else), the overall effect of the subsidy policy is to achieve the same production objective as the export subsidy, but without the consumption-side cost.

The principle behind the argument we've given here is quite a general one, with applicability to many other situations that arise in trade policy. As a very general rule, whenever trade policy of some kind can be used to achieve some production-level or consumption-level objective, there will always be an alternative policy taxing or subsidizing production or consumption directly that will achieve the desired goal at a smaller welfare cost. This is known as the Bhagwati-Ramaswami Rule, and the intuition for it is fairly simple. Trade-whether imports or exports-is always the difference between domestic production and domestic consumption of a good. When trade policy is used to influence domestic production (consumption) it will unavoidably also affect domestic consumption (production) of the same good. But subsidies or taxes, on either production or consumption, affect only the activity at which they are directed, without affecting the other. As a result, production-side objectives can be achieved without the consumption-side costs, and consumption-side objectives can be achieved without the production-side costs that always accompany the use of trade policy.

\section{Other Non-Tariff Barriers}

Policymakers always feel pressure from powerful interests opposed to freer trade. If those seeking protection can organize and exert political pressure more effectively than those who stand to lose from protection, government may find that pressure hard to resist. Yet today countries are increasingly bound together in a world trading system that has officially embraced the principle of freer trade. Through the GATT, and the WTO, countries have committed themselves to a variety of tariff rationalization and reduction programs. Policymakers caught between the international drive toward freer trade and the pressure for protection have found creative ways to have their cake and eat it too: ways they can avoid direct abrogation of their international obligations, while at the same time yielding in some degree to domestic interests seeking protection.

The UNCTAD system for tracking trade control measures includes 316 different types in all, only 32 of which are directly tariff-related measures. The rest-fully 91 per cent of all types of trade barriers that have been officially identified, categorized, and trackedare non-tariff barriers to trade or NTBs. Import (and export) quotas are important NTBs, of course, but there are many others, and they take many different forms. Some are nominally related to national defense; some to protecting wildlife; some aim to curb drug abuse; some to ensure minimum local content; and the list goes on. Table 6.2 provides a broad overview, by different country groups, of the extent to which the principal (core) NTBs are used across tariff lines. While there is considerable variation in the proportion of tariff lines subject to NTBs, both across and within the broad country 
Table 6.2 Percentage of tariff lines subject to core NTBs.

\begin{tabular}{|c|c|c|c|c|c|c|}
\hline \multirow[b]{2}{*}{ Country group } & \multirow[b]{2}{*}{ Years } & \multicolumn{2}{|c|}{ Average } & \multirow[b]{2}{*}{ Std. dev. } & \multirow[b]{2}{*}{$\max }$. & \multirow{2}{*}{$\begin{array}{c}\text { Percentage } \\
\text { with greater } \\
\text { than } 15 \% \\
\text { coverage }\end{array}$} \\
\hline & & Simple & Weighted & & & \\
\hline High-income Non-OECD (7) & 1994-2001 & 17.7 & 18.2 & 13.7 & 43.5 & 57.1 \\
\hline High-income OECD (9) & $1996-2001$ & 29.0 & 29.5 & 8.1 & 36.9 & 88.9 \\
\hline Developing countries (65) & 1992-2001 & 15.7 & 18.9 & 16.9 & 69.7 & 38.5 \\
\hline Low income (20) & 1993-2001 & 6.2 & 10.0 & 8.9 & 40.2 & 5.0 \\
\hline Middle income (45) & 1992-2001 & 20.0 & 22.9 & 17.9 & 69.7 & 53.3 \\
\hline
\end{tabular}

Source: Ng, F. K. T., "Frequency Coverage Ratio of Non-Tariff Barriers (NTBs) by Country," World Bank Trade Research.

groupings, it is clear from the data that NTBs affect a great deal of international trade. Here, we will look at just two of the most important types of NTBs. ${ }^{1}$

\section{Anti-Dumping Actions}

Under WTO rules, a firm can be accused of dumping if it charges a lower price in its export market than it does in its home market for the same good. In competitive world markets, firms have no power to unilaterally set price: market demand and market supply do that. Dumping is therefore something that can only occur "naturally" in markets that are dominated by relatively few firms with enough market power to set their own prices. In addition, the firms must be able to separate their home and export markets, otherwise resale of the product from the low-price to the high-price market would make it impossible for the firm to charge different prices.

When dumping occurs it is generally regarded as "unfair trade" (though many economists do not see it this way). WTO rules allow countries that can demonstrate "material injury" to their domestic producers caused by dumping from foreign firms to take anti-dumping actions in response. These will typically involve authorization for a departure from general non-discrimination rules allowing the injured party to impose additional or anti-dumping duties on imports of the good

1 During the 1970 s and 1980s, some countries negotiated Voluntary Export Restraint (VER) and Voluntary Import Expansion (VIE) agreements with major trading partners. "Results-based" NTBs like these, at odds with longstanding principles of the GATT and the WTO aimed at building a "rules-based" world trading system, are no longer commonly used. 
from the specific country whose firm is deemed guilty of dumping. These duties, though, are generally not to exceed the minimum necessary to offset the damage done by the dumping.

It is relatively easy to initiate anti-dumping actions, so they are often the policy of choice for protectionist influences. Table 6.3 gives some idea of the frequency with which such actions have been taken by WTO members over the period 1995-2008. The US initiated quite a few anti-dumping actions against other industrialized countries over this period, but both the US and the EU initiated many more against developing countries than they did against each other. Developing countries, too, have initiated a large number of anti-dumping actions against other developing countries over the same period. India has initiated by far the most anti-dumping

Table 6.3 The anti-dumping Top 20, 1995-2008.

\begin{tabular}{|c|c|c|c|}
\hline \multicolumn{2}{|c|}{ Top 20 initiators } & \multicolumn{2}{|c|}{ Top 20 Targets } \\
\hline Country & Number & Country & Number \\
\hline India & 564 & China & 677 \\
\hline United States & 418 & Korea & 252 \\
\hline European Union & 391 & United States & 189 \\
\hline Argentina & 241 & Taiwan & 187 \\
\hline South Africa & 206 & Indonesia & 145 \\
\hline Australia & 197 & Japan & 144 \\
\hline Brazil & 170 & Thailand & 142 \\
\hline China & 151 & India & 137 \\
\hline Canada & 145 & Russia & 109 \\
\hline Turkey & 137 & Brazil & 97 \\
\hline Korea & 108 & Malaysia & 90 \\
\hline Mexico & 95 & Germany & 83 \\
\hline Indonesia & 73 & European Union & 69 \\
\hline Egypt & 65 & Ukraine & 61 \\
\hline Peru & 64 & South Africa & 58 \\
\hline New Zealand & 53 & Italy & 46 \\
\hline Colombia & 43 & Singapore & 44 \\
\hline Malaysia & 43 & Spain & 44 \\
\hline Thailand & 39 & Turkey & 44 \\
\hline Israel & 32 & UK & 44 \\
\hline
\end{tabular}

Source: WTO data compiled by antidumpingpublishing.com 
actions of any nation, and China has been the most frequent target by a very large margin.

Economists are of many minds on the issue of dumping. If the dumping is predatory in nature-intended by the foreign firm to drive domestic firms out of business so that the foreign firm would then be free to exercise greater monopoly power-dumping would be something to oppose. If, however, a foreign firm sells at a high price in its home market and a lower price in its export market because competitive or other market conditions in the export market require it to do so, there seems no good reason to oppose it.

\section{SPS Measures}

Economist Robert Baldwin has likened the long post-war process of multilateral negotiations under the GATT and WTO, and the success they've had in reducing traditional forms of trade restrictions such as tariffs, quotas, and subsidies, as something akin to draining a swamp. As the water level has been made to steadily recede, it has revealed all the, "snags and stumps of non-tariff barriers that still have to be cleared away" (Baldwin, 2000). Many of the most gnarly stumps and nettlesome snags are now found in the different ways that countries regulate sanitation and protect the health of their plant and animal life. Is a regulation that imported wine be "cooked" to a certain temperature before being admitted into the USA a legitimate means of safeguarding California agriculture from French parasites, or is it a way of reducing the complexity, and so the allure, of the French product so that fewer buyers will want to buy it? Is a ban on the importation of poultry from countries not free of Newcastle disease a legitimate means of protecting the health of poultry and the public in Britain-the only country free of the disease-or is it an unfair means of protecting British poultry farmers from competition on the European continent?

Where public health and safety of the food supply are involved, a country's vital interests can truly be at stake. However, the potential for anti-competitive mischief in the abuse of a country's sovereign right to establish its own Sanitary and Phyto-sanitary Measures (SPS) measures is also obvious. Recent trade disputes between the EU and US over genetically modified food products have been among the most highly publicized examples of the difficulties, and the mutual suspicion, cross-country differences of this sort can create. But it is also a very real problem for developing countries. Agricultural exports from developing countries, where enforcement of domestic SPS measures may not yet be uniform and fully up to international standards, can be an easy target for agricultural interests in the importing countries around which to rally public and political support for protection.

Recognizing the legitimate demands of both importing and exporting countries, and the potential for abuse, member countries in the WTO have worked to harmonize 
cross-country SPS measures, to make them more transparent and to forge agreement on what shall constitute "good science" in determining the legitimacy of new or existing regulations in this area. Developed countries have been subject to the provisions of the SPS Agreement since 1995, developing countries since 1997, and least-developed countries since 2000. This remains, however, an important area of ongoing discussion and negotiation.

\section{SumMarY}

We have examined the principal instruments of trade policy, paying special attention to the impact each has on resource allocation and the distribution of welfare. Much of what has been discussed is summarized in Table 6.4.

Some broad patterns emerge from our analysis. In the case of a small trading country, restrictions on trade will tend to favor some at the expense of others but, as a general rule, result in a net dead-weight loss in national welfare as each introduces production-side and consumption-side inefficiencies compared to free trade. This suggests strongly that when distributional goals are the ultimate objectives of policy, using trade policy instruments in pursuit of those objectives is inefficient. More direct means of redistribution that do not distort market prices from their free trade levels, and so do not lead to the associated production-side and consumption-side inefficiencies, should be able to achieve those same objectives at lower social cost. When the objective of policy is not redistribution, but instead to encourage production, trade policy will again be an inefficient means of achieving the objective since it affects both consumption and production at once. In such cases, subsidies to production will achieve the same production goal with no consumption-side effect, and so lower social cost.

There are, however, some qualifications. For the most part, we have assumed competitive world markets on which the trading country has no appreciable market power. One important exception we considered is the optimal tariff in the case of a large country: by exploiting its market power on the world market, a large trading country may be able to turn its terms of trade in its favor sufficiently to ensure an overall national welfare gain. This comes at the expense of its trading partners, however, and so is likely to provoke retaliation. Ensuing tariff wars will generally be welfare reducing for all.

There are other qualifications and extensions to our analysis that arise when home country and world markets are imperfectly competitive. In such cases, opportunities for strategic behavior by firms, and by governments, can qualify and even reverse some of our conclusions about the effects of certain policy instruments. A careful analysis of these exceptions is beyond the scope of this chapter, but will be taken up in others. 
Table 6.4 Impact of trade policy on resource allocation and welfare.

\begin{tabular}{|c|c|c|c|c|c|c|c|c|}
\hline \multirow[b]{3}{*}{ Target } & \multirow[b]{3}{*}{ Instrument } & \multicolumn{2}{|c|}{ Resource Allocation } & \multicolumn{3}{|c|}{ Distribution } & \multirow[b]{2}{*}{ Net } & \\
\hline & & & & Consumer & Producer & Government & & \\
\hline & & Consumption & Production & welfare & welfare & revenue & welfare & \\
\hline \multicolumn{9}{|l|}{ Imports } \\
\hline & Tariff & & & $Y$ & & & & \\
\hline & Small country & & & & & T & & \\
\hline & Large country & & & & & & & (a) \\
\hline & Quota & $\downarrow$ & 1 & $\downarrow$ & 个 & ? & $\downarrow$ & (b) \\
\hline & VER (importing country) & & & & & None & & (c) \\
\hline & Anti-dumping duties & Same as tariff & & & & & & \\
\hline \multicolumn{9}{|l|}{ Exports } \\
\hline & Export tax & & $\downarrow$ & T & $\downarrow$ & & $\downarrow$ & \\
\hline & Export subsidy & $\downarrow$ & & $\downarrow$ & 个 & $\downarrow$ & $\downarrow$ & \\
\hline & Tariff preferences & $\downarrow$ & & $\downarrow$ & $\boldsymbol{T}$ & None & $\uparrow$ & (d) \\
\hline & VIE (importing country) & 个 & $\downarrow$ & $\uparrow$ & $\downarrow$ & $\downarrow$ & $\downarrow$ & (e) \\
\hline \multicolumn{9}{|c|}{ Production } \\
\hline & Production subsidies & & & & & & & \\
\hline & Importables & None & T & None & T & $\downarrow$ & $\downarrow$ & (f) \\
\hline & Exportables & None & 个 & None & 个 & $\downarrow$ & & (g) \\
\hline
\end{tabular}

Notes-

(a) Transfer from foreign producers to government. May provoke retaliation, with welfare loss.

(b) Government revenue depends on method for allocating licenses.

(c) Transfer from importing country consumers to exporting country producers.

(d) Transfer from importing country consumers to exporting country producers.

(e) Transfer from importing country producers and government to exporting country producers.

(f) Smaller welfare loss than tariff with equivalent protective effect.

(g) Smaller welfare loss than export subsidy with equivalent effect on production. 


\section{A P P E N D I X}

\section{Consumer and Producer Surplus}

To weigh costs and benefits from alternative policies, economists require some sort of dollardenominated measure that can be aggregated and compared across individuals affected by those policies. Two commonly used measures of this sort are consumer surplus and producer surplus.

\section{Consumer Surplus}

By consumer surplus we mean the excess value a consumer attaches to having a unit of a good over and above what she has to pay for it. Consumer surplus thus measures, in dollars, the net welfare gain a consumer realizes from buying a unit of the good.

Figure 6.A1 depicts an ordinary market demand curve for some good. Typically, we would read the demand curve "over and down," asking, "at such and such price, how many units of the good will consumers want to buy?" We could, instead, though, read it "up and over," asking, "what is the maximum price some consumer would be willing to pay for some particular unit of the good?" If we ask the consumers depicted in Figure 6.A1 that question about the first unit, someone would answer, " $P_{1}$." Then $P_{1}$, and so, also, the area of the rectangle with base 1 unit in width and height $P_{1}$, measures some consumer's maximum willingness to pay for the very first unit of this good consumed. This maximum willingness to pay is the total value that the consumer attaches to having one unit of the good.

With one unit being consumed, we could ask consumers how much one of them would be willing to pay to have another. According to the demand curve, $P_{2}$, and so again also the area of the rectangle with base 1 unit and height $P_{2}$, would measure some (perhaps other) consumer's willingness to pay for that second unit. We could ask it again of our consumers for the third

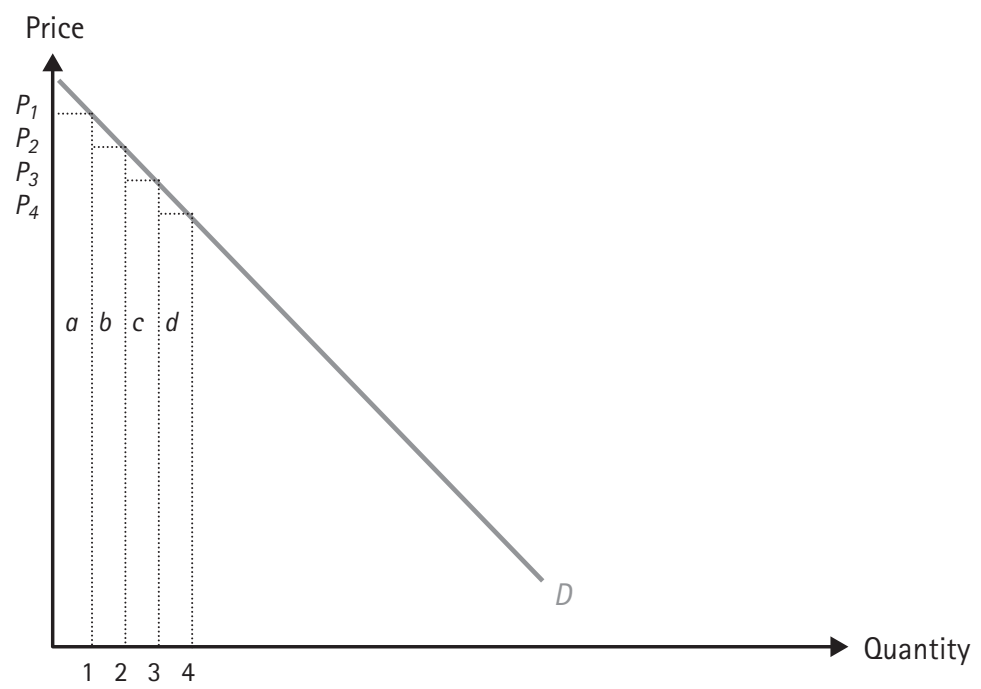

FIGURE 6.A1 Area under the demand curve measures willingness to pay. 
unit, and the fourth unit in turn. Each time, the rectangle with base 1 unit and height first $P_{3}$, then $P_{4}$, would measure some consumer's maximum willingness to pay for successive units of the good. But then an amount of money equal to the sum of the areas of those rectangles, or $a+b+c+d$, must measure the willingness of some group of consumers to pay for a total of four units of this good.

If we were now to simply change the scale of measurement along the horizontal axis, making the distance between successive units of the good smaller and smaller, before too long the area of the rectangles $a+b+c+d$ in Figure 6.A1 would become indistinguishable from the whole area beneath the market demand curve, up to four units. By this same reasoning, and with appropriately chosen scales, we may therefore regard the entire area underneath a market demand curve, up to any number of units, $Q$, as a measure of the total willingness to pay for a total of $\mathrm{Q}$ units by consumers as a group. As a result, economists often regard the area under a demand curve as a measure of the total value consumers as a group attach to having a total of $Q$ units to consume.

But consumers must usually pay something for what they get to consume. Suppose our consumers are allowed to buy $Q_{1}$ units at a fixed price, $P$, per unit. Their total outlay is $P^{\star} Q_{1}$, or the area of the rectangle marked $b_{1}$ in Figure 6.A2. Getting something worth $a_{1}+b_{1}$ in exchange for payments of $b_{1}$, leaves consumers as a group better off, net, by the amount of area $\boldsymbol{a}_{\boldsymbol{1}}$. This is consumer surplus on this transaction and, as you see, it always measures, in dollar-terms, the net gain that consumers as a group realize from the transaction concerned.

If consumers were free to buy as much or as little of this good as they chose, the demand curve tells us they would want to buy a total of $Q_{2}$ units-the point on the market demand curve at price, $P$. Notice that the additional $Q_{2}-Q_{1}$ units cost consumers an additional outplay equal to area $b_{2}$, but those units have a value to those consumers totaling $a_{2}+b_{2}$, so consumers as a group enjoy an additional, or incremental consumer surplus on those new units equal to $a_{2}$.

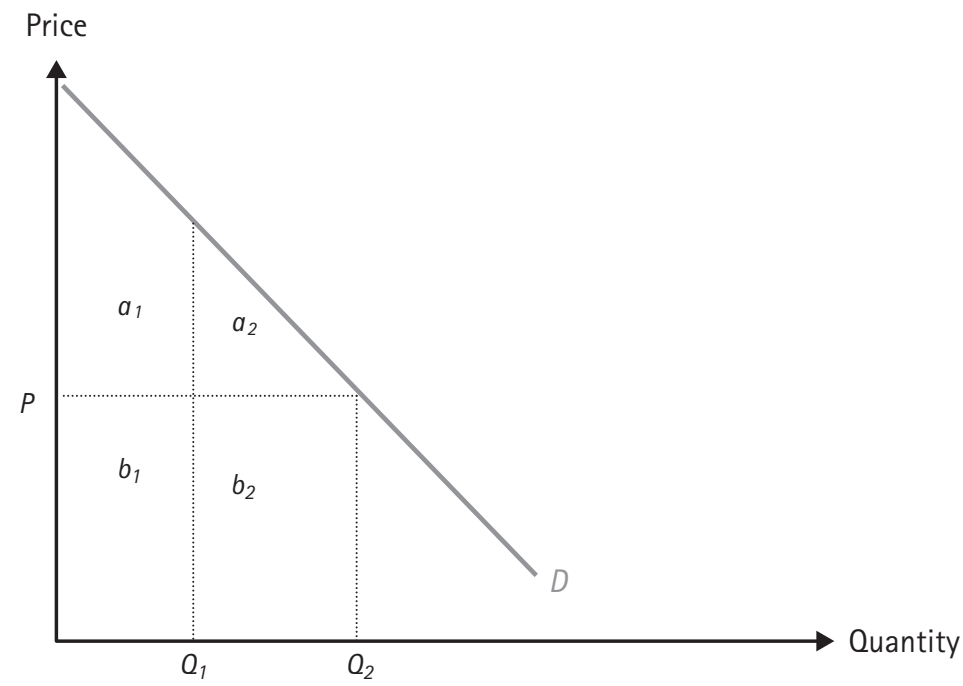

FIGURE 6.A2 Consumer surplus measures consumers' net gain. 


\section{Producer Surplus}

On the other side of any market transaction, firms provide goods to consumers in exchange for money payment. By producer surplus we mean any amount a firm earns in that transaction over and above the minimum that would have been necessary to make it just willing to agree to the transaction. Producer surplus thus measures, in dollars, the net welfare gain a producer realizes from a transaction.

Producer surplus can be seen on familiar graphs too. In Figure 6.A3, the market supply curve of a large number of perfectly competitive firms is depicted and, normally, we would read that supply curve "over and down," asking how many units all firms together would offer for sale at some fixed price per unit. We could, though, read it "up and over," instead, asking, for any given unit of the good, what is the minimum payment some firm would be willing to accept to provide it. If we ask that question of the firms depicted in Figure 6.A3 about the first unit, one of them would answer, " $P_{1}$." Then $P_{1}$, and so also the area of the rectangle with base 1 unit and height $P_{1}$, measures the minimum payment some firm would require in order to be willing to provide that first unit. By a process now familiar, we could ask, in turn, the minimum some firm would require in order to provide the second, then the third, then the fourth units. Stepping back, and asking instead the minimum payment our group of firms as a whole would require in order just to be willing to provide a total of four units for sale, we know what the answer would be: the whole of the area $a+b+c+d$. If, again, we were to simply change the scale of measurement along the horizontal axis, making the distance between successive units of the good smaller and smaller, before long the area of the rectangles $a+b+c+d$ would become indistinguishable from the area underneath the firm's supply curve, up to four units. By this same reasoning, and with appropriately chosen scales, we may therefore regard the entire area underneath a market supply curve up to any number, $Q$, units of the good as measuring the minimum total payment firms as a group would require in order to be just willing to supply $Q$ units.

In Figure 6.A4, then, the minimum firms as a group would require in order to provide $Q_{1}$ units is measured by the area $b_{1}$. But what would any firm consider in determining the minimum payment it needed in order to provide one or more of those $Q_{1}$ units? Surely, such a payment

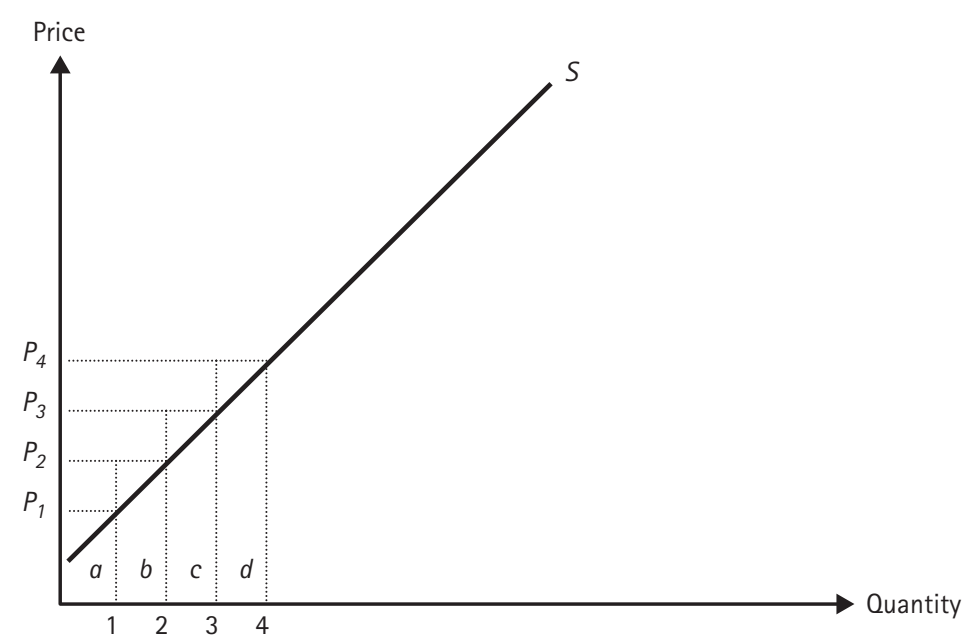

FIGURE 6.A3 Area under the supply curve measures resource cost. 
would need to cover the cost of any labor, capital, or other resources the firm must acquire to produce the output it provides. That area $b_{1}$, therefore, must also measure the total cost of all resources that all firms, and so society, must devote to producing those $Q_{1}$ units.

Now suppose that firms are able to sell $Q_{1}$ units at a price of $P$ per unit. The total revenue earned by firms would be $P^{*} Q_{1}$ or area $a_{1}+b_{1}$ in Figure 6.A4. Receiving payment of $a_{1}+b_{1}$ in exchange for something the firm would be just willing to sell for $\boldsymbol{b}_{\boldsymbol{1}}$ leaves the firm better off, net, by the amount of area $a_{1}$. This is producer surplus on this transaction and, as you see, it always measures, in dollars, the net gain that firms as a group realize from the transaction concerned.

If firms were free to sell as much or as little as they chose, the supply curve tells us they would want to sell a total of $Q_{2}$ units-the point on the market supply curve at price, $P$. Notice that firms would be willing to supply the additional $Q_{2}-Q_{1}$ units for an additional payment equal to area $b_{2}$, the cost of the additional resources needed to produce that increment in output. But firms receive an additional payment totaling $\mathrm{a} 2+b_{2}$, so they enjoy an additional, or incremental producer surplus on those new units equal to $a_{2}$.

\section{Social Welfare}

With separate measures of consumer welfare and producer welfare in hand, we could form a simple measure of overall social welfare arising from transactions in a single market by taking the sum of consumer and producer surplus:

$$
S W=C S+P S .
$$

Figure 6.A5 illustrates. Suppose that for some reason-perhaps due to government rules and regulations restricting buyers' and sellers' behavior-only $Q_{1}$ units of a good are bought and sold in some market at a price of $P$ per unit. From those transactions, consumers enjoy $Q_{1}$ units of the good, worth a total of $a_{1}+b_{1}+c_{1}$ to them. They must pay producers $b_{1}+c_{1}$, giving consumer surplus of $a_{1}$. Producers receive revenues of $b_{1}+c_{1}$ for the $Q_{1}$ units on which they must expend resources worth $c_{1}$ to produce, giving producer surplus of $b_{1}$. Notice that the sum of consumer and producer surplus-the whole of area $a_{1}+b_{1}$-measures the total of net benefits received by many different individuals in society-some of them consumers and some of them producers-as a result of the transactions described. We may regard that sum as the total of net gains to someone in society from the underlying activities of producing, selling, and consuming those $Q_{1}$ units of the good, over and above the value of society's resources that were expended in the process. The division of this sum between consumer surplus and producer surplus is easy to see in the figure, and so it is easy for us to see how these net gains are distributed between consumers and producers of this good in society.

We can use these methods to compare different market outcomes from an overall social point of view: one market outcome can be judged better than another from the viewpoint of society as a whole if the sum of net benefits to consumers and producers-the sum of consumer and producer surplus-is larger in the one market outcome than it is in the other.

In Figure 6.A5 suppose that new government policies cause the number of units produced and consumed to rise to $Q_{2}$, while market price remains at $P$. Consumer surplus on those $Q_{2}$ units at that price totals $a_{1}+a_{2}$. Producer surplus totals $b_{1}+b_{2}$. The sum of consumer and producer surplus is now $a_{1}+a_{2}+b_{1}+b_{2}$. Since this is larger than it was when only $Q_{1}$ units were produced and consumed, the total of all net gains to consumers and producers throughout society is now higher than it was before. In that sense, the market outcome providing $Q_{2}$ units can be judged better for society as a whole than the one providing only $Q_{1}$ As a general rule, the very same principles enable us to judge any market outcome as better than any other from 


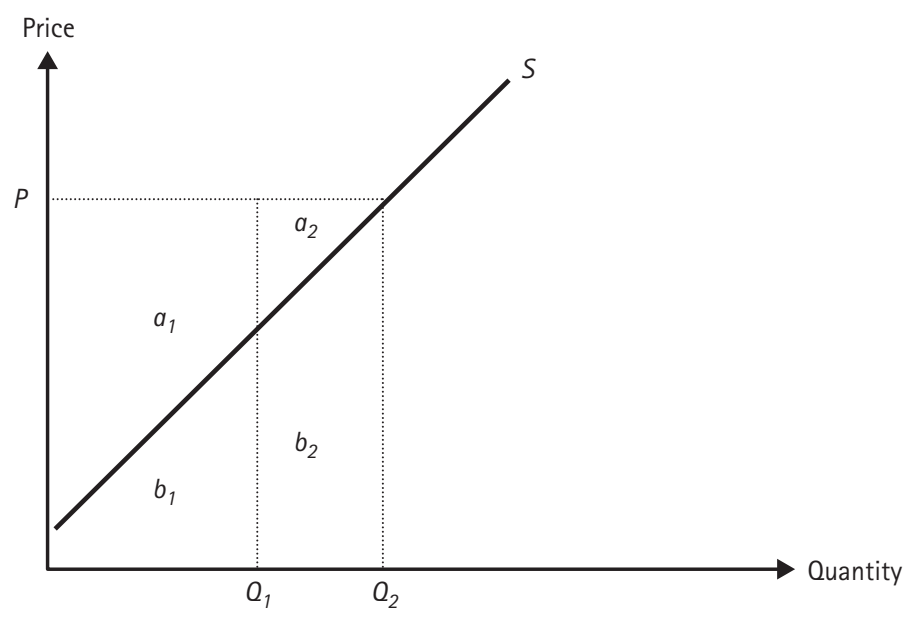

FIGURE 6.A4 Producer surplus measures producers' net gain.

a social point of view if the sum of consumer and producer surplus is higher in the one than it is in the other.

The careful, and skeptical, reader will have noticed that when the social value of market outcomes is compared in this way, we treat a dollar's net welfare gain to any one person in society - any consumer or any producer-has having the same significance to society as a dollar's net welfare gain to any other person in society-whether consumer or producer. Similarly, we treat a dollar's net welfare loss to some person as representing no loss in the welfare of society as long as some other person-anyone else-enjoys a dollar's net welfare gain at the same time.

The sum of consumer and producer surplus, used as an index of social welfare, does, in fact, bring decidedly utilitarian moral values to the exercise: individuals are treated in a completely symmetric way, with no favorites, and the welfare of society as a whole is being reckoned by the simple sum of net benefits to all its members. For some economists, and some policymakers, this is the view they take and defend: individuals either should, as a moral proposition, or must, as a practical one, be treated equally in this manner when making public policy. Others will not be comfortable with this point of view, taking, instead, the position that the distribution between advantaged and disadvantaged individuals within society is, and ought to be, an important concern of those making policy. Even if one takes this position, though, the sum of consumer and producer surplus still provides an important and useful guide to selecting among different policies that impinge on markets.

To see why, look again at Figure 6.A5. The policy that implements output level $Q_{1}$ gives total surplus of $a_{1}+b_{1}$. The policy implementing output level $Q_{2}$ gives total surplus greater than that by $a_{2}+b_{2}$. Since the size of the overall social welfare "pie" is bigger in the second case than it is in the first, it must be possible when the second policy is implemented to ensure that everyone has a slice of that larger pie that is no smaller than the one they would have had under the first policy, and still there will be pie left over to divide among people in any way desired. Economists call such a change as we're describing-one where no one is made any worse off and at least some are made better off-a Pareto improvement in welfare. Whenever the sum of consumer and producer surplus is increased, there is always the potential for a Pareto improvement in welfare. Of course, turning the potential for Pareto improvement into an actual Pareto improvement 


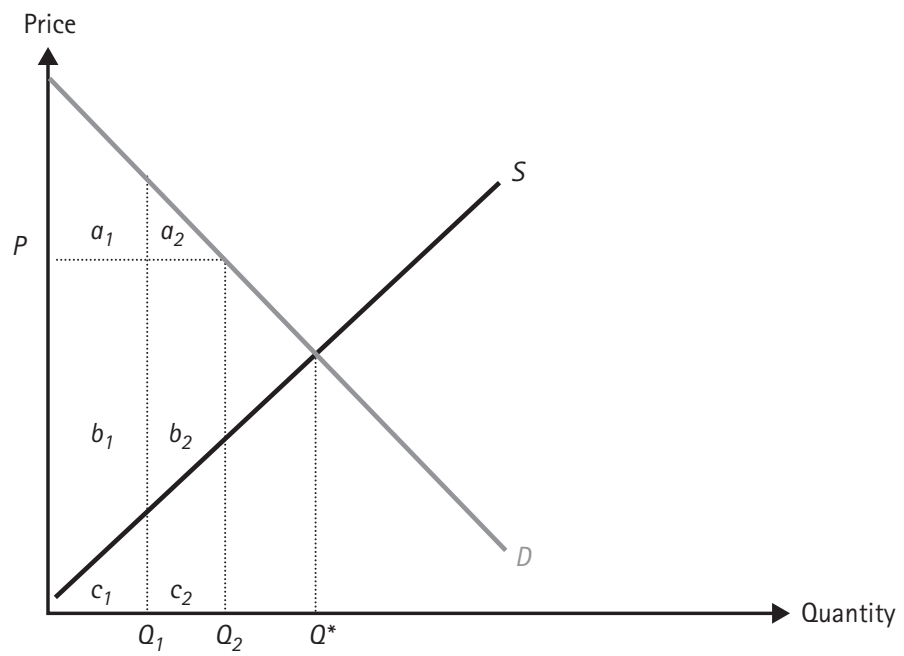

FIGURE 6.A5 Social welfare as the sum of consumer and producer surplus.

will often require some form of redistribution-say though lump-sum taxes or subsidies-to also be part of the policy package.

But what if the sum of consumer and producer surplus is as large as it can possibly be? In Figure 6.A5, when output is at $Q^{*}$ the sum of producer and consumer surplus will be maximizedequal in amount to the entire area between market demand and market supply to the left of $Q^{*}$. If the welfare "pie" is as big as it can possibly be, there will be no way to give any one person a larger slice without, at the same time, giving someone else a smaller slice. Further Pareto improvements in welfare will be impossible. Economists call such situations Pareto efficient.

Notice that output level $Q^{*}$ in Figure A5 is the equilibrium level of output we would expect to arise from unhindered market trading between buyers and sellers-the laissez-faire market outcome-if this were a properly functioning competitive market. (We've not drawn in the equilibrium market price that would prevail because that is not important at the moment.) It is no coincidence that the equilibrium level of output in a competitive market is Pareto efficient. In fact, economists call that very important property of competitive markets The First Welfare Theorem of competitive economics!

The First Welfare Theorem helps you understand why economists are often reluctant to recommend any kind of policy that interferes with properly functioning competitive markets. If such market equilibria maximize the sum of consumer and producer surplus, and so are Pareto efficient, then any policy intervention that changes the market outcome in any way can only, at best, redistribute welfare toward some and away from others: and, more often than not, it will also cause the overall level of welfare-the size of the social welfare "pie"-to shrink. When that happens, no matter what the policymaker's distributional objectives might be, the economist would argue that they can be better met-with lower net welfare cost to society-by leaving the market equilibrium alone and addressing those distributional objectives directly, though an appropriate system of lump-sum taxes and subsidies.

For our work in this chapter, it is wise, though, to ask how the arguments and methods presented here must be amended if government does involve itself in the market. For example, if the government were to introduce a tax causing the price consumers pay to rise, and the 
price producers receive to fall, both consumer and producer surplus would fall. But should we necessarily conclude that overall social welfare declined, too? After all, the government now collects tax revenue it did not have before, and it will presumably do something with that revenue. If we take the view that a dollar of tax revenue collected by government will find its way, somehow and somewhere, to benefit someone in society by a dollar, then all we have to do is include those government revenues as an equal part of the overall social calculation. In cases where government plays a role, then, we would simply expand the index of social welfare in equation (6.A.1) to include any net government revenues collected, $R$, as follows:

$$
S W=C S+P S+R .
$$

This is the index of social welfare we use throughout the chapter.

\section{REFERENCE}

Baldwin, R. 'Regulatory Protectionism, Developing Nations and a Two Tier World Trade System’ Brookings Trade Forum, 2000, pp. 237-94. 